\title{
The Potential Carbon Offset Represented by a Green Roof
}

\author{
Ammy Marie George \\ Palmyra, VA
}

Bachelor of Science in Landscape Architecture

West Virginia University

1996

A Thesis presented to the Graduate Faculty

of the University of Virginia in Candidacy for the Degree of

Master of Arts

Department of Environmental Sciences

University of Virginia

May 22, 2012 


\section{$\underline{\text { Abstract }}$}

As a roof covered by plant material, a green roof is purported to have the potential to mitigate $\mathrm{CO}_{2}$ emissions in urban areas. This thesis offers an academic review for two avenues of research that provide seemingly reasonable methods to reduce $\mathrm{CO}_{2}$ in the atmosphere: carbon sequestration and reduction of the demand for energy generated from the combustion of fossil fuels.

The first avenue is the carbon sequestration potential of a green roof, which centers on the plants: i.e. the plant biomass represents the $\mathrm{CO}_{2}$ taken up through photosynthesis. The second avenue of reducing $\mathrm{CO}_{2}$ involves a reduction in the quantity of energy that commercial users demand to heat and cool a space. The magnitude of the carbon offset depends upon the plant selection, soil depth and irrigation regime on the green roof. Academically, the carbon offset under optimal conditions could be as much as $1.22 \mathrm{~kg}$ $\mathrm{CO}_{2} \mathrm{~m}^{-2} \mathrm{yr}^{-1}$. This thesis will provide a review of both avenues to demonstrate how the variables of plant type, soil depth and irrigation regime affect the carbon offset potential of a green roof. Additionally, this thesis will offer a critical assessment of the feasibility of the two avenues in the world beyond the scientific setting. 


\section{Table of Contents}

Acronyms

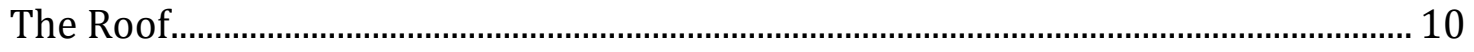

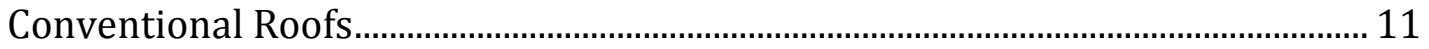

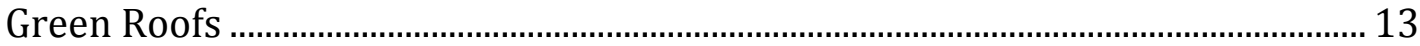

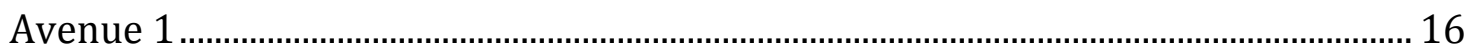

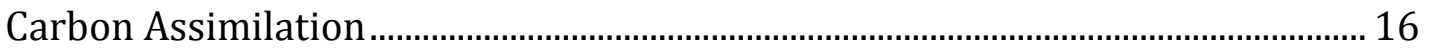

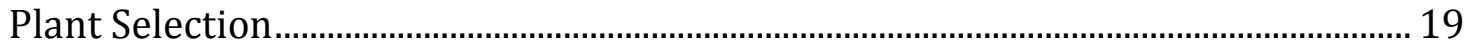

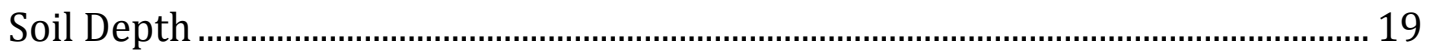

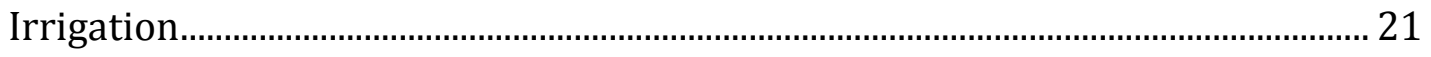

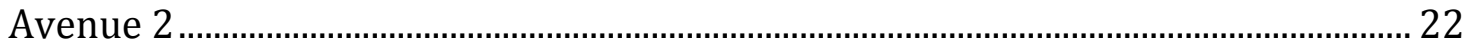

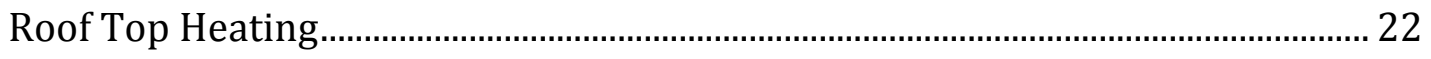

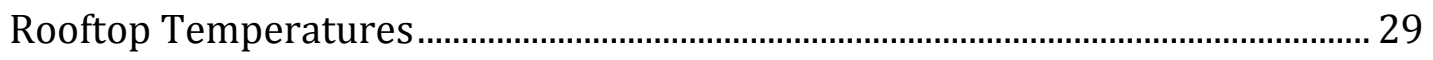

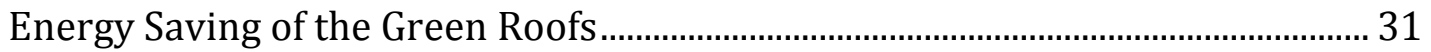

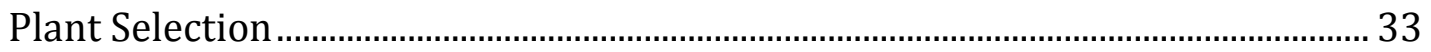




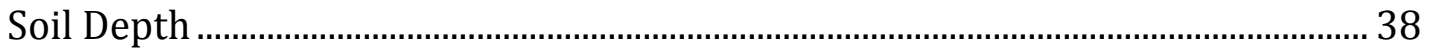

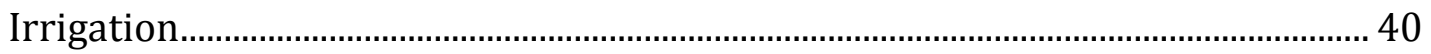

Comparison of $\mathrm{CO}_{2}$ Emissions for Commercial Buildings ..................................... 42

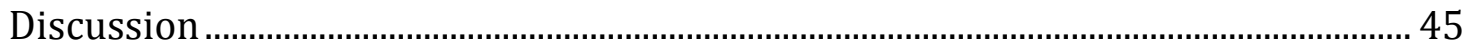

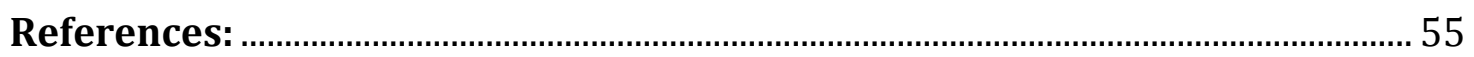

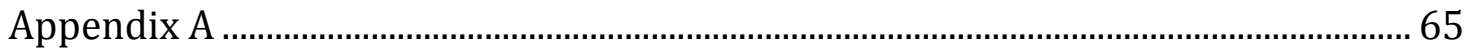




\section{Acronyms}

Bldg.

BUR

CAM

$\mathrm{CO}_{2}$

Comm.

$\mathrm{cm}$

DOE

EPA

Hrs

$\mathrm{kg}$

$\mathrm{kWh}$

LAI

$\mathrm{m}$

$\operatorname{Tg}$

Yr

$\mu \mathrm{m}$
Building

Built Up Roof

Crassulacean Acid Metabolism

Carbon Dioxide

Commercial

Centimeter

Department of Energy

Environmental Protection Agency

Hours

Kilogram

Kilowatt hour

Leaf Area Index

Meter

Teragrams

Year

Nanomole 


\section{Introduction}

A green roof is a rooftop with plants covering its surface. The green roof, which is also known as a living roof, has had a long history. For centuries, Northern Europeans have used green roofs on their homes, sheds, and barns for added warmth in the harsh winters; many other Europeans used sod covering over their cellars to keep them cool. The settlers on the American prairie built their houses with the materials on hand - sod for the walls and roofs. This provided them with shelter from the elements and a measure of insulation that a wooden structure typical of that time did not offer. In the 1960's, the Germans established the modern green roof style that we are familiar with today (Klinkenborg, 2009).

Within the last decade, there has been a growing interest in the United States for design/engineering solutions to mitigate environmental extremes within the built environment. As a result, designers have been looking into ways to bring sustainable elements into urban and suburban areas. The green roof is one of the design solutions currently being implemented for that purpose. The green roof has multiple positive characteristics that may benefit the built and natural environments. The range of benefits that have been advocated in scientific/ technical literature and review articles includes the following: stormwater attenuation (VanWoert et al., 2005a; Connelly et al., 2006; livingroofs, 2010), reduction of heat island effect (Grant, 2006; Skinner, 2006; Sonne, 2006; Alexandri and Jones, 2008; livingroofs, 2010;), energy conservation (DOE, 2004; Banting et al., 
2005; VanWoert et al., 2005b; Sonne, 2006; Oberndorfer et al., 2007; livingroofs, 2010), air quality improvement (DOE, 2004; Banting et al., 2005; Getter et al., 2009; livingroofs, 2010; Nui et al., 2010), noise attenuation (livingroofs, 2010), habitat creation and conserving biodiversity (Burgess, 2004; Gedge and Kadas, 2005; Matteson and Langellotto, 2008) .

The growing appeal of design solutions like that of a green roof has closely followed the mounting concerns over rising atmospheric $\mathrm{CO}_{2}$ concentrations and global warming. Some of that scientific research focuses on how a wide spread application of green roofs might be a viable design solution as a method to mediate global warming (NAS, 2008). From this area of study, the thesis will highlight two avenues of research as a means to reduce $\mathrm{CO}_{2}$ in the atmosphere: carbon sequestration and reduction of the demand for energy generated from the combustion of fossil fuels. The carbon sequestration potential of a green roof centers on the plants: i.e. the plant biomass represents the $\mathrm{CO}_{2}$ taken up through photosynthesis. Kristin Getter and her colleagues illustrated the enormous carbon sequestration potential of a citywide green roof installation through their research. Their study concluded that a citywide installation of green roofs would be the equivalent of "removing more than 10,000 midsized SUVs or trucks off of the road for a year" (Getter et al., 2009). However, both past and present research focuses only on existing green roof design standards. The studies have not taken into account the differing amounts of carbon assimilated through the three pathways of photosynthesis: C3, C4 and CAM. 
Additionally, the research does not touch upon what happens to that carbon storage potential during extended dry conditions that are common on a roof. These concepts are important in understanding the true carbon sequestration potential of a green roof.

The second avenue of reducing $\mathrm{CO}_{2}$ involves a reduction in the quantity of energy that commercial users demand to heat and cool a space. Currently, most of this energy produced in the United States and the rest of the world is from the combustion of coal, natural gas and fuel oils (EIA, 2010b; EIA, 2011a). By reducing the demand for energy for heating and cooling, there will be a corresponding reduction in $\mathrm{CO}_{2}$ emitted in the atmosphere. In "A Green Roof Model for Building Energy Simulation Programs," D. J. Sailor demonstrated that commercial buildings could cut the use of natural gas by $10 \%$ and the use of electricity by $2 \%$ by installing a green roof (Sailor, 2008). This article and others focus on the cost-benefit analysis of energy savings, in this paper this information is expanded upon to provide an estimate of the reduction of $\mathrm{CO}_{2}$ emissions possible through the widespread installation of green roofs.

Both avenues hold a possibility to reduce $\mathrm{CO}_{2}$ levels in the atmosphere if green roofs were utilized over a wide area. However, the potential $\mathrm{CO}_{2}$ offsets of both avenues are sensitive to the influence of several variables: the type of plants selected, the soil depth and irrigation regime. This academic review will quantify the ideas of carbon 
sequestration and reduction in $\mathrm{CO}_{2}$ emissions to identify the potential carbon offset that a green roof represents. The effects of each variable will be discussed along with how it may be possible to optimize the $\mathrm{CO}_{2}$ offset of a green roof.

Additionally, the thesis will offer a critical assessment of the feasibility of the two carbon offset avenues in the world beyond the scientific setting. The assessment will focus in on factors such as the life-cycle carbon trends of materials that are common to commercial construction, such as concrete, steel and iron. The production of concrete and steel/iron are two of the five primary industries that contribute to nearly one-quarter of the global carbon dioxide emissions annually (Price et al., 2001; IEA, 2007). Furthermore, the climate of the region where the green roof is constructed/installed will determine the final design of the green roof and will control to the plant type selection, soil depth and irrigation regime. The will affect the level of optimization that can realistically take place. The analysis of these points is important in understanding all of the environmental costs and benefits that could arise with a citywide installation of green roofs.

\section{Methods and Assumptions}

In this document, the calculations use the assimilation rates from previous scientific experiments that provided individual rates for different species of each plant type. The assimilation rates were also given under different watering conditions: wellwatered; water stressed where watering events were 3 to 7 days apart; critical water stress where watering events were over 7 days but under 30 days apart; and 
drought where watering events were over 30 days apart. Those assimilation rates were converted to $\mathrm{kg} \mathrm{CO}_{2} \mathrm{~m}^{-2} \mathrm{yr}^{-1}$ where necessary. Then those results were averaged based upon the plant function type: hardy succulents, or grasses and forbs.

For the overall thermal performance of the roof, the conventional roof has two components while the green roof has four. The conventional roof components are the structural parts along with the boundary layer of air above the roof surface (Alexandri and Jones, 2007). The green roof components include the structural parts, the soil, the plant canopy (leaves) and the boundary layer of air above the roof surface (Alexandri and Jones, 2007). For the analysis of the thermal performance of these roof types, the calculations presented are based upon the assumption that the structural components and the boundary layer of air above the roofs surface will act in a similar fashion. Therefore, the calculations within this document will focus on the surface of the conventional roof and the soil and plant layer of the green roof.

For the analysis of the electrical demands, the calculations focus on commercial buildings. There are many uses that fall under the broad category of commercial buildings such as education, food service and sales, health care, hotels and similar lodging accommodations, retail (excluding malls), office, public assembly, religious worship, service, warehousing and storage (EIA, 2006). Therefore, the commercial buildings within a city can make up a substantial portion of the available building stock. On average, the commercial sector accounts for $19 \%$ of the energy use within 
the United States. It is also the second largest end user of electricity, with industry being number one (EIA, 2010a). Buildings within this category tend to utilize an average of $5 \%$ of their annual electric use for heat and an average of $14 \%$ for cooling (EIA, 2010a). In the review of the literature, the average commercial building uses $0.06 \mathrm{kWh} \mathrm{m}^{-2}$ of electric per year to heat the space and $0.19 \mathrm{kWh} \mathrm{m}^{-2}$ to cool it (EIA, 2010a). From this information, we can now determine how much fossil fuel is burned to create the electricity to heat or cool a building.

Table 1 Quantity of fossil fuel burned to heat and cool a building with electricity per year.

\begin{tabular}{|l|c|c|c|}
\hline \multicolumn{1}{|c|}{ Fossil Fuel } & $\begin{array}{c}\text { Energy Produced by } \\
\text { Power Plant }\end{array}$ & $\begin{array}{c}\text { Fossil Fuel Burned to } \\
\text { Heat Space by Electric }\end{array}$ & $\begin{array}{c}\text { Fossil Fuel Burned to } \\
\text { Cool Space by Electric }\end{array}$ \\
\hline \multicolumn{1}{|c|}{$1 \mathrm{Kg}$} & $\mathrm{kWh} \mathrm{Kg}^{-1}$ & $\mathrm{Kg} \mathrm{m}^{-2} \mathrm{yr}^{-1}$ & $\mathrm{Kg} \mathrm{m}^{-2} \mathrm{yr}^{-1}$ \\
\hline Coal & 2.63 & 0.02 & 0.07 \\
\hline Natural Gas & 4.83 & 0.01 & 0.04 \\
\hline Fuel Oil & 4.41 & 0.01 & 0.04 \\
\hline
\end{tabular}

(Table compiled from information from: ORNL, date unknown; Hong and Slatick, 1994; Shephelsky, 2002; Fisher, 2003; Yan, 2004; Linder and Hoinki, 2007; EIA, 2010a; Natural Gas.org, 2010; Teach Coal, 2010)

Electrical generation is dominated by the use of fossil fuels. Approximately $47 \%$ of the fuel used to produce electricity is from the combustion of coal in the United States; natural gas makes up 19\%; fuel oil makes up 1\% (EIA, 2011a).

The average amount of $\mathrm{CO}_{2}$ released by the burning of coal within the United States is $1.00 \mathrm{~kg} \mathrm{CO}_{2} \mathrm{kWh}^{-1}$ (Hong and Slatick, 1994; EIA, 2011b). The average amount of $\mathrm{CO}_{2}$ released by natural gas is $0.54 \mathrm{~kg} \mathrm{CO}_{2} \mathrm{kWh}^{-1}$, while fuel oils release $0.79 \mathrm{~kg} \mathrm{CO}_{2}$ $\mathrm{kWh}^{-1}$ of $\mathrm{CO}_{2}$ (Hong and Slatick, 1994; EIA, 2011b). When these amounts are adjusted to represent the percentage of each fossil fuel used to generate electricity, 
the amount of $\mathrm{CO}_{2}$ emitted is $0.86 \mathrm{~kg} \mathrm{CO}_{2} \mathrm{kWh}^{-1}$ (EIA, 2011a). In this document, calculations use this value for the $\mathrm{CO}_{2}$ emitted for the electrical demand for heating and cooling a building.

Table 2 Commercial sector electric and natural gas consumption with the resulting $\mathrm{CO}_{2}$ emissions with a conventional roof.

\begin{tabular}{|c|c|c|c|c|c|c|}
\hline \multirow{3}{*}{ Use } & \multicolumn{3}{|c|}{ Energy Consumption } & \multicolumn{3}{|c|}{$\mathrm{CO}_{2}$ Emitted } \\
\hline & kWh yr-1 & $\begin{array}{l}\text { kWh per } \\
\text { Bldg. } \mathrm{yr}^{-1}\end{array}$ & $\begin{array}{c}\mathrm{kWh} \mathrm{m}^{-2} \\
\mathrm{yr}^{-1}\end{array}$ & $\mathrm{~kg} \mathrm{CO}_{2} \mathrm{yr}^{-1}$ & $\mathrm{~kg} \mathrm{CO}_{2} \mathrm{yr}^{-1}$ & $\begin{array}{c}\mathrm{kg} \mathrm{CO} \mathrm{CO}_{2} \mathrm{~m}^{-2} \\
\mathrm{yr}^{-1}\end{array}$ \\
\hline & $\begin{array}{l}\text { Comm. } \\
\text { Sector }\end{array}$ & Per Bldg. & Per Area & Comm. Sector & Per Building & Per Area \\
\hline \multicolumn{7}{|l|}{ Electric } \\
\hline Heating & $4.89 \mathrm{e}+10$ & $1.06 \mathrm{e}+04$ & $6.48 \mathrm{e}-02$ & $4.22 \mathrm{e}+10$ & $9.15 \mathrm{e}+03$ & $5.59 \mathrm{e}-02$ \\
\hline Cooling & $1.41 \mathrm{e}+11$ & $3.05 \mathrm{e}+04$ & $1.87 \mathrm{e}-01$ & $1.22 \mathrm{e}+11$ & $2.63 e+04$ & $1.61 \mathrm{e}-01$ \\
\hline \multicolumn{7}{|l|}{ Natural Gas } \\
\hline Heating & $3.86 \mathrm{e}+11$ & $1.52 \mathrm{e}+05$ & $7.39 \mathrm{e}-01$ & $2.09 \mathrm{e}+11$ & $8.25 \mathrm{e}+04$ & $4.01 \mathrm{e}-01$ \\
\hline \multicolumn{7}{|c|}{ Total for Heating and Cooling } \\
\hline Heat/Cool & $5.76 \mathrm{e}+11$ & $1.93 e+05$ & $9.90 \mathrm{e}-01$ & $3.73 e+11$ & $1.18 \mathrm{e}+05$ & $6.17 \mathrm{e}-01$ \\
\hline
\end{tabular}

(Table compiled from information from: Hong and Slatick, 1994; EIA, 2006; EIA, 2010a; EIA, 2011a EIA, 2011b)

For natural gas, commercial buildings use an average of $63 \%$ for heating. The average building uses $0.74 \mathrm{kWh} \mathrm{m}^{-2}$ of natural gas per year to heat the space. In this document, the calculations use the value of $0.54 \mathrm{~kg} \mathrm{CO}_{2} \mathrm{kWh}^{-1}$ for calculations of $\mathrm{CO}_{2}$ emitted for the natural gas demand for heating a building.

\section{The Roof}

A roof is designed with few things in mind: to protect the interior of the building and its occupants from the elements; to carry the live and dead loads and to transfer those loads to the building framing system; and to provide the building with dimensional stability by connecting the framing systems together (Fields, 2003). 


\section{Conventional Roofs}

A conventional roof on a commercial building is typically a flat roof. The flat roof is comprised of roof decking, insulation and a waterproofing membrane or an asphalt layer over the structural components supporting the roof (Fig. 1).

There are several types of roof decking used in commercial buildings. The most predominant type of roof deck is the metal roof deck. The metal roof deck panels are made from cold rolled steel in 22, 20, 18 or 16 gauge thicknesses. These panels provide support for the other roofing components - insulation, waterproofing and surfacing. The metal roof deck panels come with ribs of different depths $(3.8 \mathrm{~cm}$ to $19 \mathrm{~cm}$ deep) with the rib depth of $3.8 \mathrm{~cm}$ being the most commonly used (Hardy, 1997).

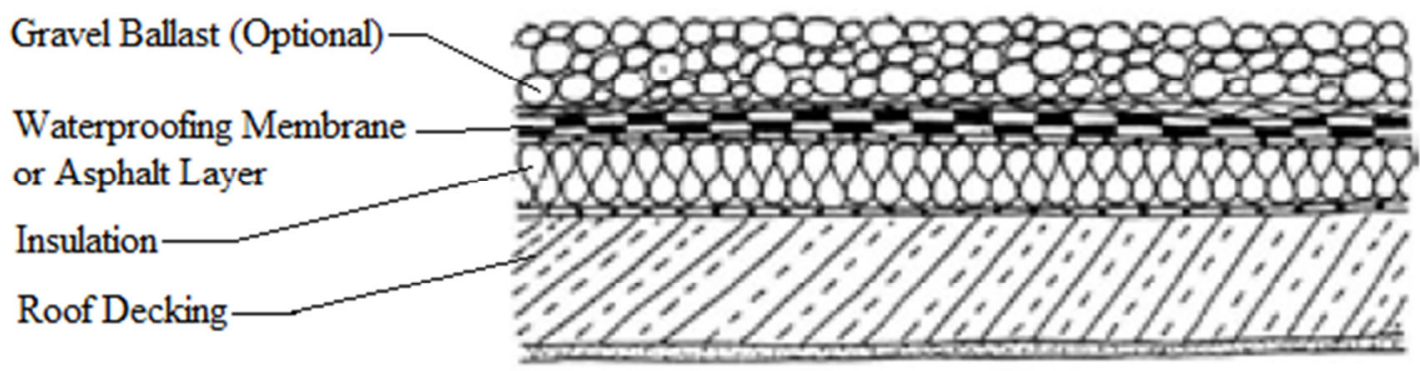

Fig. 1 Cross section of a conventional roof (Fig. 1 from DOE, 2004).

In some buildings, roof decking can be a structural cement fiberboard. Portland cement or other binding agents hold treated wood fibers together. The cement fiberboard comes in panels. Architects specify its use where the underside will be left exposed and viewed from the interior of building (Hardy, 1997). 
Concrete is another type of roof decking that comes in the form of structural concrete or lightweight concrete. Steel or concrete columns usually support the structural concrete roof due to its weight (Hardy, 1997). The materials in the category of lightweight concrete can include lightweight concrete entrained with perlite or vermiculite, gypsum or cellular concrete impregnated with pregenerated foam (Hardy, 1997). This type of roof decking does not require as much vertical support as the structural concrete roof decking. However, lightweight concrete roof decks require a base made from form boards, metal decking or structural concrete system. The structural or lightweight concrete is typically a minimum of $5 \mathrm{~cm}$ thick.

In rare instances such as small commercial buildings or older construction, builders use wood as the roof deck. Wood roof decks come in the form of wood planks or plywood. The wood planks range from $2.5 \mathrm{~cm}$ to $10 \mathrm{~cm}$ thick. A plywood deck is usually thinner with a minimum thickness of $1.5 \mathrm{~cm}$.

The next layer of the conventional roof is the insulation. Insulation comes in panels from $1 \mathrm{~cm}$ thick to $15 \mathrm{~cm}$ thick. Manufactures use a variety of materials to produce insulation: cellular glass, composite board, fiberglass, perlite, phenolic, polyisocyanurate, polystyrenes or wood fibers (Hardy, 1997). The key design strategy is to provide the highest insulating value while being as thin as possible. 
On top of the roof decking and insulation, the visible roof surface is comprised of an asphalt layer or waterproofing membrane. The asphalt layer consists of a series of layers of felt and asphalt. This type of roof covering is called asphalt built up roof (BUR). The BUR surface must be covered with a ballast of gravel, cutback asphalt coating, ceramic mineral surfaced cap sheets, or insulated concrete pavers. The waterproofing membrane is a modified bitumen roof covering, also known as a rubber roof. The most common polymers added to the asphalt to make the modified bitumen roof are atactic polypropylene and styrene butadiene styrene (Hardy, 1997). The modified bitumen roof does not require the ballast like the BUR.

\section{Green Roofs}

A green roof contains the same components seen in a conventional roof such as the roof decking, insulation and a waterproofing layer. The components unique to a green roof are the root resistance barrier, drainage and reservoir layer, filter layer, growing medium, and vegetation (Sailor, 2008; Waldbaum, 2008) as shown in Fig. 2.

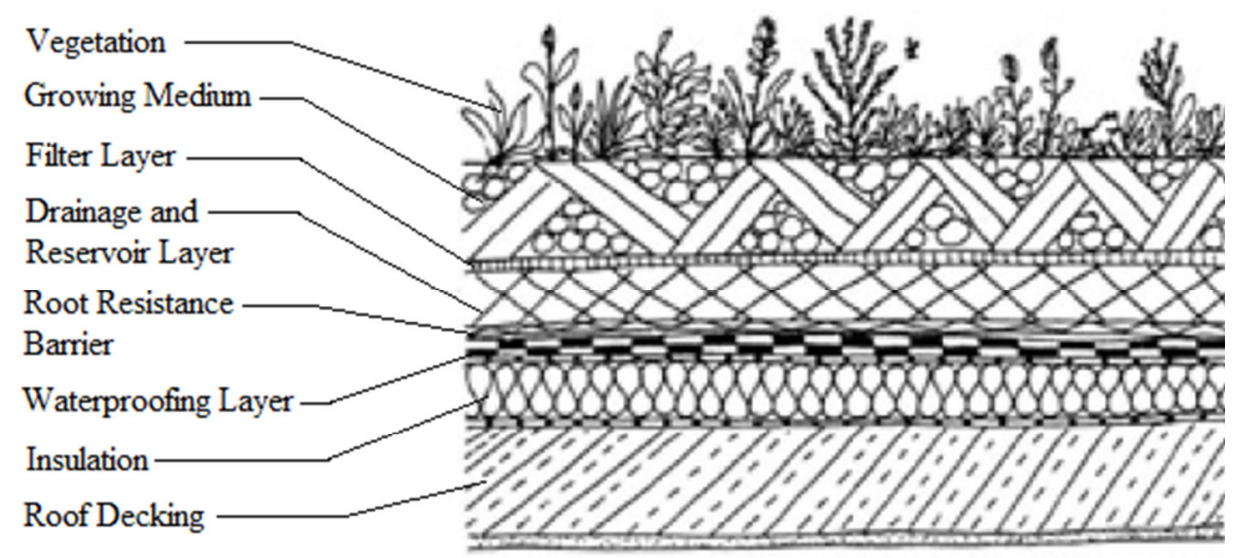

Fig. 2 Cross section of a green roof (Fig. 2 from DOE, 2004). 
The root resistance barrier protects the underlying roofing components from damage by aggressive roots (Waldbaum, 2008). The root barriers are typically made of foil or plastic. The drainage and reservoir layer is a system of continuous plastic boards with a network of wells and channels. The wells and channels capture the water from rain events, allowing the excess to drain away while holding back some for a dryer period of time (Sailor, 2008; Waldbaum, 2008). This prevents the soil from becoming waterlogged or drying out excessively over short intervals between rain events. The filter layer is typically a geo-textile fabric. It physically separates the soil and drainage layers. The filter fabric keeps the soil and roots from clogging the drainage system (Waldbaum, 2008). The growing medium and the vegetation are located on top of the filter fabric.

The vegetation and the growing medium are the main parts of the roof that differentiate a green roof from a conventional roof. As such, the variation in their application creates two categories of green roofs: the intensive and the extensive green roofs. Intensive green roofs have a deep layer of soil with a wide variety of plants: grasses, perennials, vegetables, shrubs and trees (Köhler, 2006; Kadas, 2006). The depth of the soil substrate is typically greater than $30 \mathrm{~cm}$ (Coffman and Waite, 2009). The main idea behind the intensive green roof is aesthetics; they are designed to be like a garden or park. Extensive green roofs have a thin layer of the growing medium. They utilize vegetation that can survive the extreme conditions on 
the roof (Köhler, 2006). The depth of the growing medium starts as low as $2.5 \mathrm{~cm}$ and ranges in depth up to 10 to $15 \mathrm{~cm}$ (Köhler, 2006; Sailor, 2008).

The shallow soil depths exert a great deal of influence on the plants. The most successful plants on an extensive green roof have a wide variety of characteristics that ensure their hardiness. The plants are typically low-growing, shallow rooted, have low nutrient requirements, a long life expectancy, successful self-propagation techniques (i.e. reseeding, rhizomes...), ability to establish quickly to provide a dense groundcover, resistance to environmental fluctuations, tolerant to extreme environmental conditions and low maintenance requirements (White and Snodgrass, 2003; VanWoert et al., 2005b; Durhman and Rowe, 2007; Oberndorfer et al., 2007). Therefore, the most widely used plants for green roofs are in the Sedum genus of the Crassulaceae family (Gedge and Kadas, 2005; VanWoert et al., 2005b; Köhler, 2006).

Green roofs require a special growing medium or pre-made soil. Each manufacture has a proprietary blend of ingredients patented under a registered trademark. As such, manufactures do not list the actual ingredients or percentage of each ingredient within their product literature. However, the green roof industry has set a proportion of organic and inorganic materials within the soil mixture. The organic portion of the mix is between 3 to $8 \%$ of the total weight of the soil mixture (Emilsson, 2005). The organic components may include peat moss, bark, straw, 
sawdust, leaves, wood chips, grass clippings, cellulose, compost manure, biosolids, worm castings and wood ash (Retzlaff et al., 2008). The inorganic portion of the mix may include sand, cinders, ash, pea gravel, lava, perlite, vermiculite, pumice or scoria, tire chunks, crushed brick, roof tiles and synthetic expanded slate, clay or shale (Emilsson, 2005; Retzlaff et al., 2008).

\section{$\underline{\text { Avenue } 1}$}

\section{Carbon Assimilation}

There are three photosynthetic pathways: C3, C4 and CAM; and each of the pathways have a different efficiency at assimilating $\mathrm{CO}_{2}$ under well watered and water stressed conditions. As noted above, the most popular species for a green roof are sedums most notably Sedum acre, S. album, S. montanum, S. reflexum, S. rupestre, S. sieboldii, S. telephioides, S. telephium and S. ternatum, Talinum calycinum and T. paniculatum (Sayed, 2001; Pilon-Smits et al., 1991; Gravatt and Martin, 1992). All of these subspecies are facultative CAM or C3/CAM intermediates. This means that during ideal conditions, the plants will utilize the C3 photosynthetic pathway. Then, they will switch to the CAM photosynthetic pathway during periods of stress brought about by drought, high temperatures, high salinity or changes in the photoperiod (Sayed, 2001). The switch from C3 to CAM is termed as CAM cycling. The switch between the photosynthetic pathways is predominantly seasonally dependent with C3 taking place in the spring and fall and CAM photosynthesis taking place in the peak of summer as conditions get drier (PilonSmits et al., 1991). A plant's ability to shift from C3 to CAM has a significant 
ecophysiological advantage. The C3 pathway allows for rapid growth when water is available, typically in the spring. The CAM pathway then allows for the continued metabolic activity with slower growth and water conservation during times of drought (Martin et al., 1988; Gravatt and Martin, 1992).

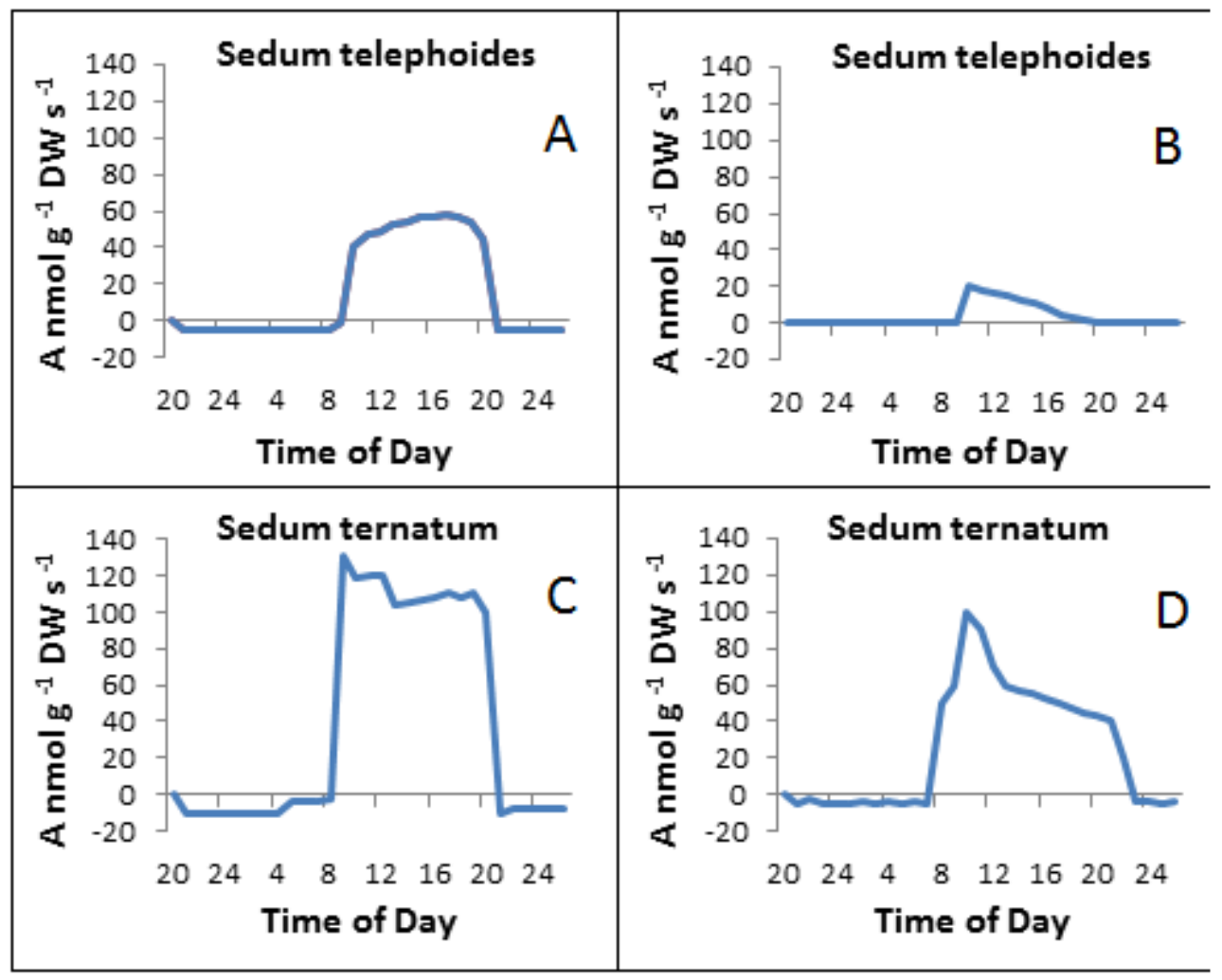

Fig. 3 Assimilation rate of sedum under well watered conditions $(A, C)$ and under water stressed conditions after three days without water (B, D) (Fig. 3 recreated from Gravatt and Martin, 1992).

While ecophysiological advantages to the CAM cycling pathway exist, research has shown there can be a drastic difference in the quantity of carbon assimilated between the two photosynthetic pathways within the C3/CAM intermediates. The amount of carbon assimilated is wholly dependent upon the water availability during the growing season. Gravatt and Martin (1992) found that S. telephioides and 
S. ternatum significantly reduced their rate of $\mathrm{CO}_{2}$ assimilation during short durations of water stress (Fig. 3). However, in their experiment, the short-term water stress events were not long enough to induce the CAM photosynthetic pathway. As the drought and water stress conditions intensify, the plant switches to the CAM photosynthetic pathway where the assimilation of $\mathrm{CO}_{2}$ only occurs at night (Fig. 4). As the water stress becomes critical, the plant will begin the CAM idling process where the stomata remained closed not only during the day but also during the night to conserve water. During this stage, the plant begins to recycle respiratory $\mathrm{CO}_{2}$ at a $100 \%$ rate (Güerere et al., 1996). Scientists presume that the process allows for the "maintenance of an active metabolic state during severe droughts" with a rapid recovery period when water becomes available again (Martin et al., 1988).

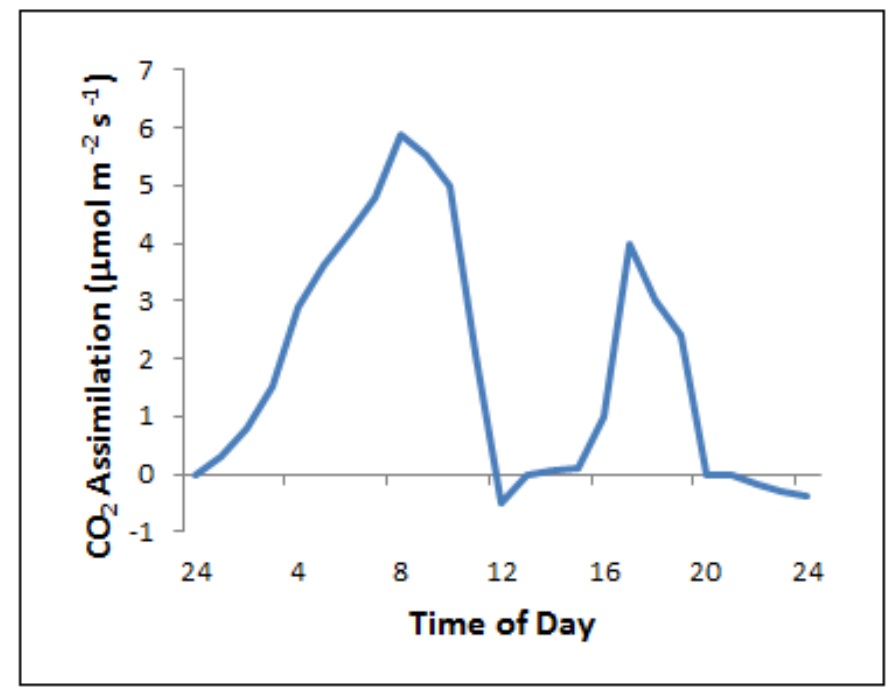

Fig. 4 CAM assimilation pattern (Fig. 4 recreated from Borland et al., 2000). 


\section{Plant Selection}

Table 3 represents the computed assimilation rates of $\mathrm{CO}_{2}$ for two plan function types and water availability conditions. The hardy succulents represent the CAM and facultative CAM photosynthetic pathway. The grasses and forbs represent C3 and C4 photosynthetic pathways. The column for well-watered represents the ideal condition where we could expect to see the optimum $\mathrm{CO}_{2}$ assimilation rates. The effects of water stress are evident by the drop in assimilation rates for both plant function types as time between watering events increases (Martin et al., 1988; Harris and Martin, 1991; Gravatt and Martin, 1992; Herrera, 2009).

Table 3 Computed Assimilation Rates

\begin{tabular}{|c|c|c|c|c|}
\hline \multirow{2}{*}{$\begin{array}{c}\text { Plant } \\
\text { Function } \\
\text { Type }\end{array}$} & $\begin{array}{c}\text { Well } \\
\text { Watered }\end{array}$ & $\begin{array}{c}\text { Water Stressed } \\
\text { (Approx. 3-7 Days) }\end{array}$ & $\begin{array}{c}\text { Critical Water } \\
\text { Stress (7+ Days) }\end{array}$ & $\begin{array}{c}\text { Drought } \\
(1+\text { Month) }\end{array}$ \\
\cline { 2 - 5 }$\left(\begin{array}{c}|c| \\
\left(\mathrm{kg} \mathrm{CO}_{2} \mathrm{~m}^{-2} \mathrm{yr}^{-1}\right)\end{array}\right.$ & $4 \mathrm{e}-08$ \\
\hline $\begin{array}{c}\text { Hardy } \\
\text { Succulents }\end{array}$ & 0.15 & 0.05 & 0.01 & 0 \\
\hline $\begin{array}{c}\text { Grasses \& } \\
\text { Forbs }\end{array}$ & 1.17 & 0.23 & 0.06 & 0 \\
\hline
\end{tabular}

(Values computed and averaged from Martin et al., 1988; Harris and Martin, 1991; Gravatt and Martin, 1992; Gurevitch, 1992; Güerere et al., 1996; Szente et al., 1998; Borland et al., 2000; Reich et al., 2003; Subke, and Tenhunen, 2004; Boddy et al., 2007; Urban et al., 2007; Ibrahim et al., 2008; Buis et al., 2009; Getter et al., 2009; Gibson, 2009; Herrera, 2009.)

\section{Soil Depth}

The soil or growing medium on a green roof is a key part of the system, just as it is to any vegetated ecosystem at ground level; the soil provides support, nutrients and moisture for the plants. On a green roof, the depth of the soil dictates the species of plants used and therefore how much $\mathrm{CO}_{2}$ can be captured each year. As noted above, the minimum soil depth for extensive green roofs is $2.5 \mathrm{~cm}$. However, scientists have found that this is not an adequate depth for plant survival. In one such experiment, only eight of 25 species survived to the next growing season on a green roof with a 
soil substrate of $2.5 \mathrm{~cm}$ depth (Durhman et al., 2007). While the remaining eight species were able to form stable communities, they were not sufficient to cover a significant portion of the roof's surface. Hence, the roof was not able to function as a "green roof"; it was merely a roof with soil. In the same experiment, the plant species had a better survival rate at $5 \mathrm{~cm}$ and $7 \mathrm{~cm}$; 12 and 14 species survived respectively (Durhman et al., 2007). At these depths, the plant species were also able to maintain cover on a significant portion of the roof's surface and propagate further in the next growing season.

In 2009, a separate study by Getter and Rowe demonstrated that there was in fact a statistically significant difference in the plant survivability between a soil depth of 5 $\mathrm{cm}$ and $7 \mathrm{~cm}$. A soil depth of $7 \mathrm{~cm}$ allowed for a greater ratio of plant survival and area coverage. They attributed the positive results of plant survival to the increased soil depth and its ability to retain more moisture. Other studies had similar results of plant survival and moisture retention for depths over $6 \mathrm{~cm}$ (Liesecke, 1998; VanWoert et al., 2005a and 2005b). Even as Getter and Rowe established that soils depths of $7 \mathrm{~cm}$ or $10 \mathrm{~cm}$ were not statistically different from each other, they maintained their belief that a greater soil depth would ensure healthier plants, allow for greater biomass accumulation and be less susceptible to the ill effects from the harsh environmental conditions on a roof (Getter and Rowe, 2009). 


\section{Irrigation}

A green roof is typically only irrigated after installation for one growing season in order to allow the plants to establish themselves. This is not the ideal case for a green roof where the main goal is $\mathrm{CO}_{2}$ assimilation and storage. Research has shown that the most biomass accumulates when the watering events are no more than two days apart (Dewey et al., 2004). As shown in Fig. 5 in the CAM or C3/CAM intermediates, if the time between watering events increases to 7, 14, 28 or 88 days, there is little biomass accumulated during those periods (Dewey et al., 2004; VanWoert et al., 2005b). The same is true for non-CAM plants. In order to maintain the photosynthetic activity and therefore sequester carbon, green roofs need to be watered at least every two days (Dewey et al., 2004; VanWoert et al., 2005b; Durhman et al., 2006).

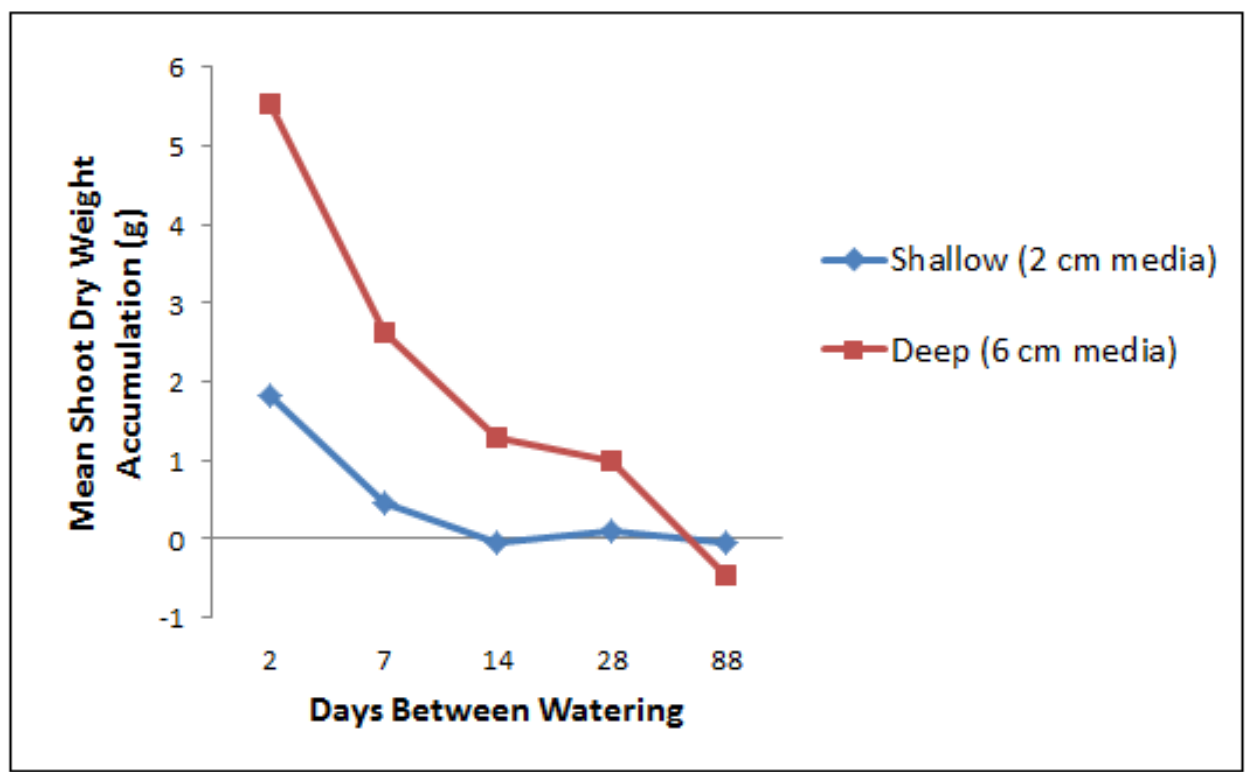

Fig. 5 Mean shoot dry weight accumulation (g) for each treatment over the course of the study. (Graph created using data from VanWoert et al., 2005b). 
The irrigation needs of the plants are also tightly bound to the quantity of biomass, the soil depth and the area coverage of the plants' foliage. For green roofs with a large quantity of biomass, there will be a greater need for water due to a greater evapotranspiration rate and water need to carry on near optimal photosynthesis and assimilation of $\mathrm{CO}_{2}$ (VanWoert et al., 2005b).

A regular irrigation schedule also allows for the benefit of allowing a more diverse plant community to survive for multiple seasons (Price et al., 2011; Schroll et al., 2011). A more diverse plant palette would provide for the use of larger, non-CAM plants with a higher assimilation rate and therefore biomass accumulation.

\section{$\underline{\text { Avenue } 2}$}

\section{Roof Top Heating}

The solar irradiance is the major energy source for the thermal load or the temperature difference between the interior and exterior of the building (Sailor, 2008; ASHRAE, 2009). The exterior temperature of the roof is influenced by the heat and mass transfer mechanisms, $Q(i)$, driven by the solar irradiance (Jacobs, 2006). These mechanisms include such processes as absorption, evaporation and adsorption. Each of these mechanisms contributes to the total heat budget of the target surface. This heat budget, which in this case is the roof, can be described with the following variables: 
$Q(1)=$ absorbed short-wave irradiance $(\lambda \leq 3 \mu \mathrm{m})$;

$Q(2)=$ absorbed long-wave irradiance $(\lambda>3 \mu \mathrm{m})$;

$Q(3)=$ convective heat exchange;

$Q(4)=$ target emittance;

$Q(5)=$ latent heat exchange by condensation/evaporation (green roof only);

$Q(6)=$ internal heat sources and/or sinks;

$Q(7)=$ heat conduction in the target (heat flux)

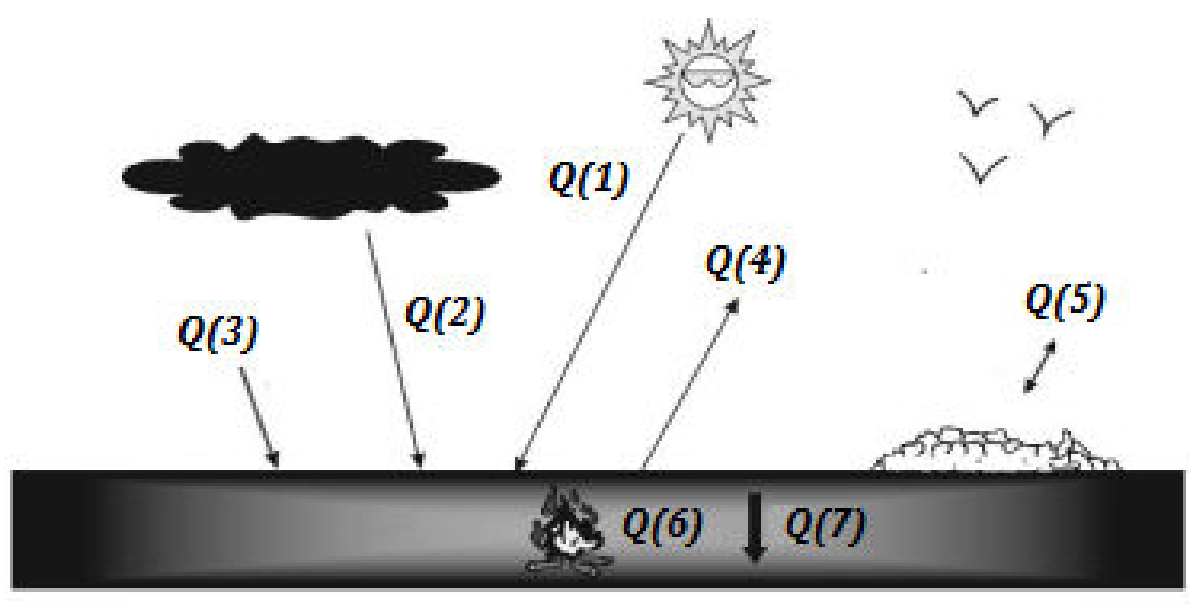

Fig. 6 Heat budget of a surface (Fig. 6 from Jacobs, 2006).

The variables in the heat budget are combined in the principle of energy conservation. This equation is used then to predict the surface temperature of the roof.

$$
\sum_{i=1}^{7} Q(i)=0 \Longrightarrow \text { physical surface temperature } T \text {. }
$$

Eq. 1 Mass Transfer Equation (Jacobs, 2006)

The materials and their physical properties of both the conventional and green roof influence the seven variables in Eq. 1. The albedo of the roofing surface determines the quantity of energy added in the form of solar irradiance. It is represented by $Q(1)$ and $Q(2)$ in Fig. 6 and in Eq. 1 . Until recently, conventional roofs have been black (Piotrowicz and Osgood, 2010). The black roofs have an albedo of 0.04 to 0.05, 
which means that $94 \%$ to $95 \%$ of the incoming solar radiation is absorbed by the roof's surface (Pon, 1999; Levy. 2000). In recent years, the building industry has been moving to the use of "cool roofs" where the visible membrane is not black; it is now white or grey. The average albedo of these products is approximately 0.6 to 0.75 (EPA, 2003). The average albedo of a green roof is approximately 0.3 (Wong et al., 2003b). While the albedo of the green roof is lower than that of the "cool roofs", the vegetation on the roof affects the latent heat exchange, $Q(5)$ which is not present on a conventional roof. The evaporation and transpiration from the plants and the soil on the green roof is directly proportional to the latent heat exchange of the green roof (Del Barrio, 1997; Alexandri and Jones, 2007; Sailor, 2008). The evaporation from the plant canopy on a green roof can deflect as much as 55\% to $80 \%$ of the energy that is conducted through a conventional roof, $Q(7)$ (Wong et al., 2003b; Tabares-Velasco and Srebric, 2009).

Two additional concepts are used to describe the thermal performance of a roof and in balancing the energy conservation equation: the thermal mass (Eq. 2) of the roof itself and the overall insulative properties of the materials used in its construction (Eq. 3 and Eq. 4). For the purposes of this paper, the concept of thermal mass relates how well a body stores, $Q(6)$, and conducts thermal energy, $Q(7)$. The thermal mass of an object can be described by the amount of energy that it takes to raise the temperature of a material. The thermal mass, $C p$, is represented by $(Q / \Delta T) / \rho V$ in the following equation: 
Eq. 2 Thermal mass (Rolle, 2000).

$$
E=m \frac{\left(\frac{Q}{\Delta T}\right)}{\rho V}{ }^{\rho V}
$$

where $E$ is the energy required to raise the temperature of a material; $m$ is the mass of the material; $Q$ is the quantity of energy transferred to the material; $\Delta T$ is the change in temperature of the material; $\rho$ is the density of the material; $V$ is the volume of the material.

The thermal mass of an object provides the resistance to change against the temperature fluctuations (Kosny et al., 2001). The thermal mass protects the interior of the building from temperature vacillation during the day by absorbing the solar energy when the outside temperature differs from that of the interior of the building. An object or, in this case, a roof that has a high thermal mass absorbs heat energy slowly and retains the absorbed energy for a longer time period, becoming a heat sink. That retained energy is then released slowly over a long period of time when the exterior boundary layer of air is cooler than the roof (Kosny et al., 2001). A building or roof with high thermal mass has three important benefits: fewer spikes occur in heating and cooling requirements; less energy is required to heat/cool than a building with low thermal mass; and a thermal lag is created (ASHRAE, 2009). A thermal lag occurs when the highs or lows in temperature of the roof do not correspond with the highs and lows of the daily temperature. 
Insulation maintains the temperatures of the interior spaces. The insulation minimizes this movement of heat energy by slowing the process down through its resistance to the energy transfer. This value is reported as the quantity of heat energy transferred through a standard thickness of a material when there is a difference of $1^{\circ} \mathrm{C}$ from one side of the material to the other (ASHRAE, 2009). Two values represent the insulative properties of a material: the thermal resistance $(R$ value) and the thermal transfer coefficient ( $U$-value). For the R-value, the larger the number, the more effective the material is at insulating the building. The opposite is true with the U-value: the smaller the number, the greater the insulation's effectiveness.

The $R$-value is the ratio of temperature across the insulator and the heat flux (heat transfer per unit area). The following equation represents the $R$-value:

$$
R=\Delta T / Q_{A}
$$

Eq. 3 Thermal resistance, R-value (Rolle, 2000)

where $R$ is the thermal resistance; $\Delta T$ is temperature difference under steady state conditions when the heat transfer is dependent only on a temperature gradient between the two materials; $Q_{A}$ is the heat transferred per unit area. When comparing various materials, the material with the higher $R$-value has a better insulative property. 
Table 4 Thermal properties of materials of conventional and green roofs. (Rolle, 2000; Kaska and Yumrutats, 2009)

\begin{tabular}{|l|c|c|c|c|}
\hline \multirow{2}{*}{ Product } & $\begin{array}{c}\text { Nominal } \\
\text { Thickness } \dagger\end{array}$ & $\begin{array}{c}\text { Thermal } \\
\text { Conductivity }\end{array}$ & $\begin{array}{c}\text { Thermal } \\
\text { Resistance }\end{array}$ & $\begin{array}{c}\text { Thermal } \\
\text { Transfer } \\
\text { Coefficient }\end{array}$ \\
\cline { 2 - 5 } & $\mathrm{m}$ & $-\lambda_{c}\left(\mathrm{~W} \mathrm{~m}^{-1}{ }^{\circ} \mathrm{C}\right)$ & ${\mathrm{R}\left(\mathrm{m}^{2}{ }^{\circ} \mathrm{C} \mathrm{W}^{-1}\right)}$ & $\mathrm{U}\left(\mathrm{W} \mathrm{m}^{-2} \mathrm{C}^{-1}\right)$ \\
\hline Asphalt & $1.0 \times 10^{-3}$ & 0.062 & $1.6 \times 10^{-2}$ & 62 \\
\hline Carbon Steel & $1.0 \times 10^{-3}$ & 43 & $2.0 \times 10^{-5}$ & 43000 \\
\hline Concrete, light & $5.0 \times 10^{-2}$ & 0.42 & $1.2 \times 10^{-1}$ & 8.4 \\
\hline $\begin{array}{l}\text { Concrete, } \\
\text { reinforced }\end{array}$ & $5.0 \times 10^{-2}$ & 1.6 & $3.1 \times 10^{-2}$ & 32 \\
\hline Fiberboard & $5.0 \times 10^{-2}$ & 0.2 & $2.5 \times 10^{-1}$ & 4 \\
\hline Soil, dry $(100 \mathrm{~cm})$ & $1.0 \times 10^{-1}$ & $0.15 \times 10^{-}$ & $6.7 \times 10^{-1}$ & 1.5 \\
\hline Soil, wet $(100 \mathrm{~cm})$ & $1.0 \times 10^{-1}$ & $0.6 \times 10^{-4}$ & $1.7 \times 10^{-1}$ & 6 \\
\hline Wood, plywood & $1.0 \times 10^{-3}$ & 0.12 & $8.3 \times 10^{-3}$ & 120 \\
\hline $\begin{array}{l}\text { XPS (Extruded } \\
\text { Polystyrene) }\end{array}$ & $2.0 \times 10^{-2}$ & 0.034 & $5.9 \times 10^{-1}$ & 1.7 \\
\hline
\end{tabular}

$\dagger$ Minimum thickness per Hardy, 1997.

The thermal transfer coefficient describes how well a building material conducts heat. The following equation represents the U-value:

$$
U=\frac{1}{R}=\frac{Q_{A}}{\Delta T}
$$

Eq. 4 Thermal transfer coefficient, U-value (Rolle, 2000).

where $U$ is the thermal transfer coefficient; $Q_{A}$ is the heat transferred per unit area; $\Delta T$ is temperature difference under steady state conditions when the heat transfer is dependent only on a temperature gradient between the two materials. The $U$-value is the inverse of the $R$-value; as such, the material with the lower $U$-value is a better insulator. The $U$-value also relates to a material's thermal mass. Materials with a 
high thermal mass typically have moderately low $U$-values. Table 4 shows the typical R-values and U-values for material typically found in a commercial roof.

Insulation does not entirely prevent heat flux through the roof; therefore, the ambient temperature of the outside environment still influences the building's interior temperature even when the building is fully insulated. Therefore, the interior temperature is largely a function of the magnitude of the heat flux through the walls and roof. This heat flux into the building from the external environment is a function of the temperature differential between the interior and exterior environment and the thermal conductivity $\left(-\lambda_{c}\right)$ of the medium through which the energy passes (Lundholm, 2010). It is the principle of energy conservation. The surface temperature can be predicted by determining the transfer of energy, mass into, out of and through the roof.

$$
-\lambda_{c}\left(\frac{\partial T}{\partial z}\right)=Q(t)
$$

Eq. 5 Thermal conductivity (Jacobs, 2006).

where $-\lambda c$ is equal to the thermal conductivity; $\delta T$ is equal to the change in temperature; $\delta z$ is equal to the width of the material; $Q(t)$ is equal to surface temperature.

In Table 5, the U-value is generated for several typical roof-decking configurations for both conventional and green roofs. The values demonstrate how well a series of 
materials will work together to provide insulation to a space. Both the conventional roof and green roof have similar overall thermal resistance values. However, the green roofs provide a greater level of thermal resistance and insulative properties for the building's interior space due to the soil and vegetation layers.

Table 5 Overall thermal performance of typical conventional and green roofs (Rolle, 2002; Wong et al., 2003b; Connelly et al., 2006; Kosareo and Ries, 2007; Alexandri and Jones, 2007; Kaska and Yumrutas, 2009)

\begin{tabular}{|c|c|c|c|c|c|}
\hline \multirow[t]{2}{*}{ Roof } & \multirow[t]{2}{*}{ Materials } & $\begin{array}{c}\text { Thermal } \\
\text { Conductivity }\end{array}$ & Thickness & $\begin{array}{l}\text { Thermal } \\
\text { Resistance }\end{array}$ & $\begin{array}{c}\text { Overall Thermal } \\
\text { Resistance }\end{array}$ \\
\hline & & $-\lambda_{c}\left(\mathrm{~W} \mathrm{~m}^{-1}{ }^{\circ} \mathrm{C}\right)$ & $\mathrm{m}$ & $\mathrm{R}\left(\mathrm{m}^{2} \mathrm{C} / \mathrm{W}\right)$ & $\mathrm{U}\left(\mathrm{W} \mathrm{m}^{-2} \mathrm{C}^{\circ}\right)$ \\
\hline \multicolumn{6}{|c|}{ Conventional } \\
\hline \multirow{4}{*}{1} & Carbon Steel & 43.00 & 0.001 & 0.0000 & \multirow{4}{*}{0.39} \\
\hline & Polystyrene* & 0.03 & 0.085 & 2.5000 & \\
\hline & Fiberboard & 0.20 & 0.013 & 0.0625 & \\
\hline & SBS roofing & 0.06 & 0.001 & 0.0081 & \\
\hline \multicolumn{6}{|c|}{ Green } \\
\hline \multirow{5}{*}{2} & Carbon Steel & 43.00 & 0.001 & 0.0000 & \multirow{5}{*}{0.31} \\
\hline & Polystyrene* & 0.03 & 0.085 & 2.5000 & \\
\hline & Fiberboard & 0.20 & 0.013 & 0.0625 & \\
\hline & SBS roofing & 0.06 & 0.001 & 0.0081 & \\
\hline & Soil & 0.15 & 0.100 & 0.6667 & \\
\hline
\end{tabular}

* Insulation layer

\section{Rooftop Temperatures}

The temperature of the roof membrane is related to the heat flux through the roof to the interior of the building. In the summer, there can be a marked difference between the membrane temperatures of a conventional roof when compared to those of a green roof (Fig 7). The peak temperature on the conventional roof membrane ranges from $65^{\circ} \mathrm{C}$ to $88^{\circ} \mathrm{C}$ in the height of summer (EPA, 2003; Lui and Baskaran, 2003; Oberndorfer et al., 2007). The peak temperature measured on the green roof membrane temperature ranges between $22^{\circ} \mathrm{C}$ to $40^{\circ} \mathrm{C}$, depending on the 
kind of vegetation used and soil depth (Niachou et al., 2001; Lui and Baskaran, 2003; Gedge and Firth, 2004; Connelly et al., 2006; Sonne, 2006; Oberndorfer et al., 2007; Sailor, 2008; Teemusk and Mander, 2010). The research also points to a higher temperature fluctuation of the membrane throughout a 24-hour period on a conventional roof; the median fluctuation averaged $42^{\circ} \mathrm{C}$ to $47^{\circ} \mathrm{C}$. The median fluctuation on the green roof averaged $5^{\circ} \mathrm{C}$ to $7^{\circ} \mathrm{C}$ within the same time frame (Connelly et al., 2006; Teemusk and Mander, 2010).

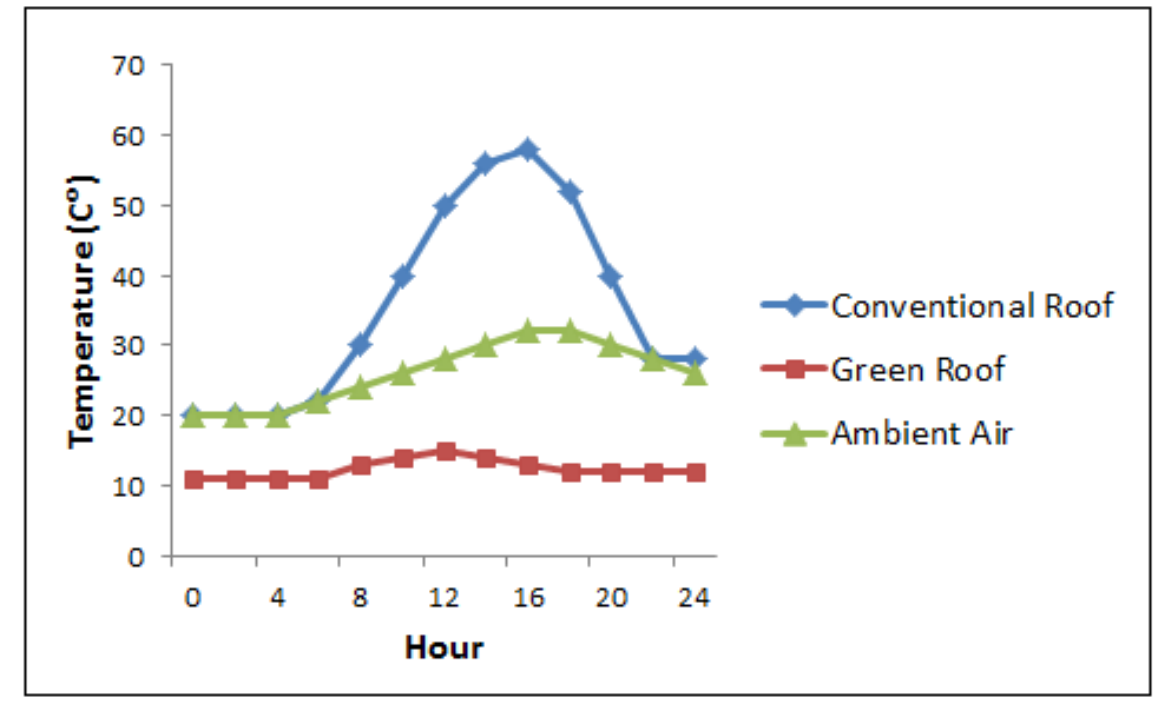

Fig. 7 Temperature profile for conventional and green roofing systems in comparison to the ambient outside air on a summer day (Fig. 7 recreated from Ouldboukhitine et al., 2011).

The green roof also offers insulative benefits for the building during the winter. In the winter, the average temperature of the membrane of both roofs did not show a tremendous difference as seen in the summer: the average for both was near $0^{\circ} \mathrm{C}$ (Gedge and Firth, 2004; Teemusk and Mander, 2010). However, on the green roof, the membrane temperature ranged from $8^{\circ} \mathrm{C}$ to $-18^{\circ} \mathrm{C}$ throughout a 24 -hour period 
on a conventional roof. The membrane temperature ranged from $7^{\circ} \mathrm{C}$ to $-10^{\circ} \mathrm{C}$ within the same period.

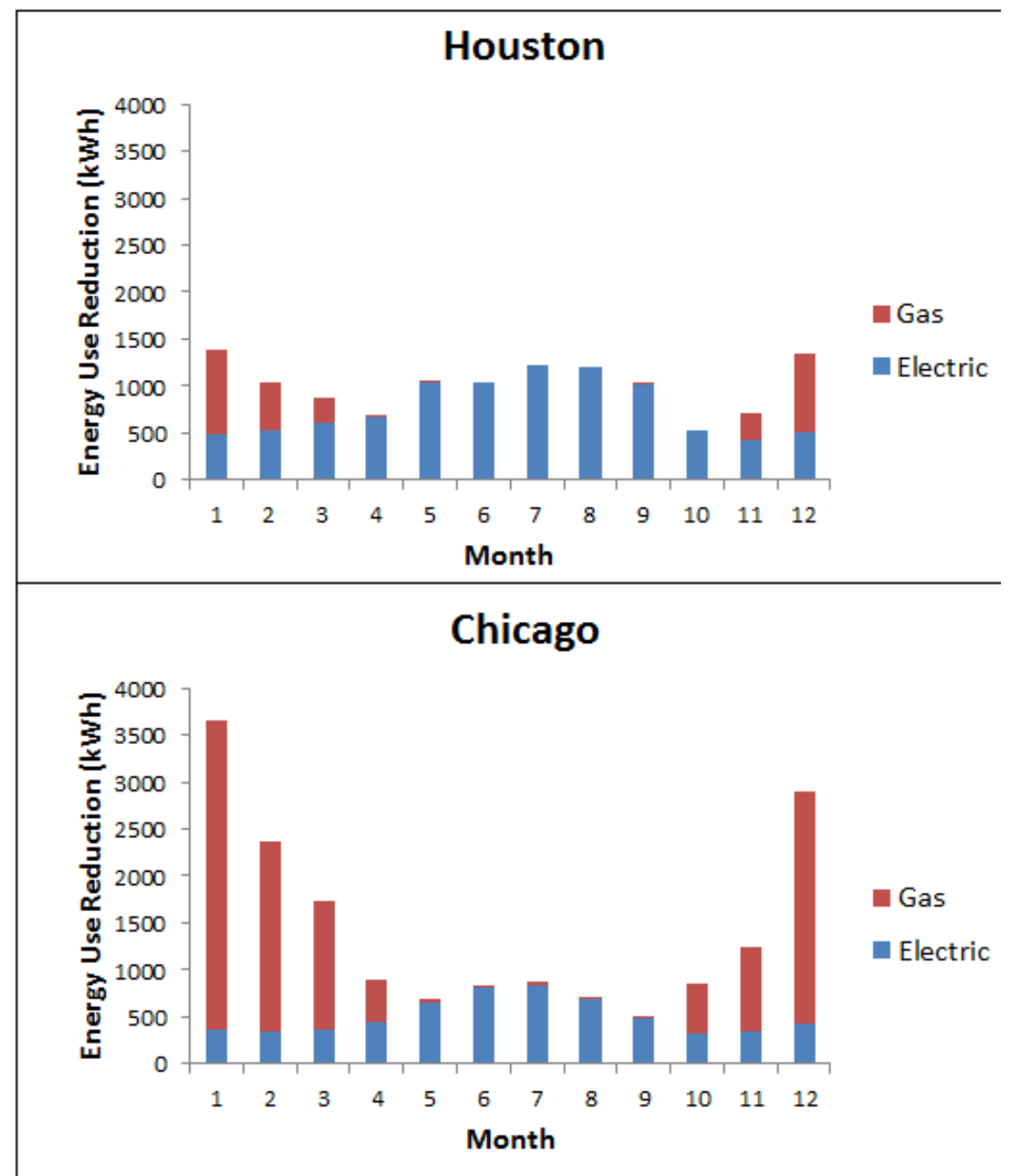

Fig. 8 Monthly electricity and natural gas consumption reduction associated with the baseline green roof construction relative to the control roof membrane in each of the two test case cities-Chicago, and Houston (Fig. 8 recreated from Sailor, 2008).

\section{Energy Saving of the Green Roofs}

To calculate the energy savings in a building with a green roof, Sailor modeled two professional/office buildings, one in Chicago and one in Houston (Sailor, 2008). When compared to a conventional roof, the typical green roof cut the annual 
electricity load by $2 \%$ as well as the annual demand for natural gas by $9 \%$ in Chicago and $11 \%$ in Houston (Fig 8).

Similar studies have been performed in the United States, Canada, Greece, Singapore and England. These studies reported an average of $7 \%$ reduction in the electrical demands for buildings with a green roof compared to those with a conventional roof (Niachou et al., 2001; Liu and Baskaran, 2003; Wong et al., 2003a; Banting et al., 2005; Connelly et al., 2005; Lui and Minor, 2005; Saiz et al., 2006; Kosareo and Ries, 2007; Santamouris et al., 2007; Carter and Keeler, 2008).

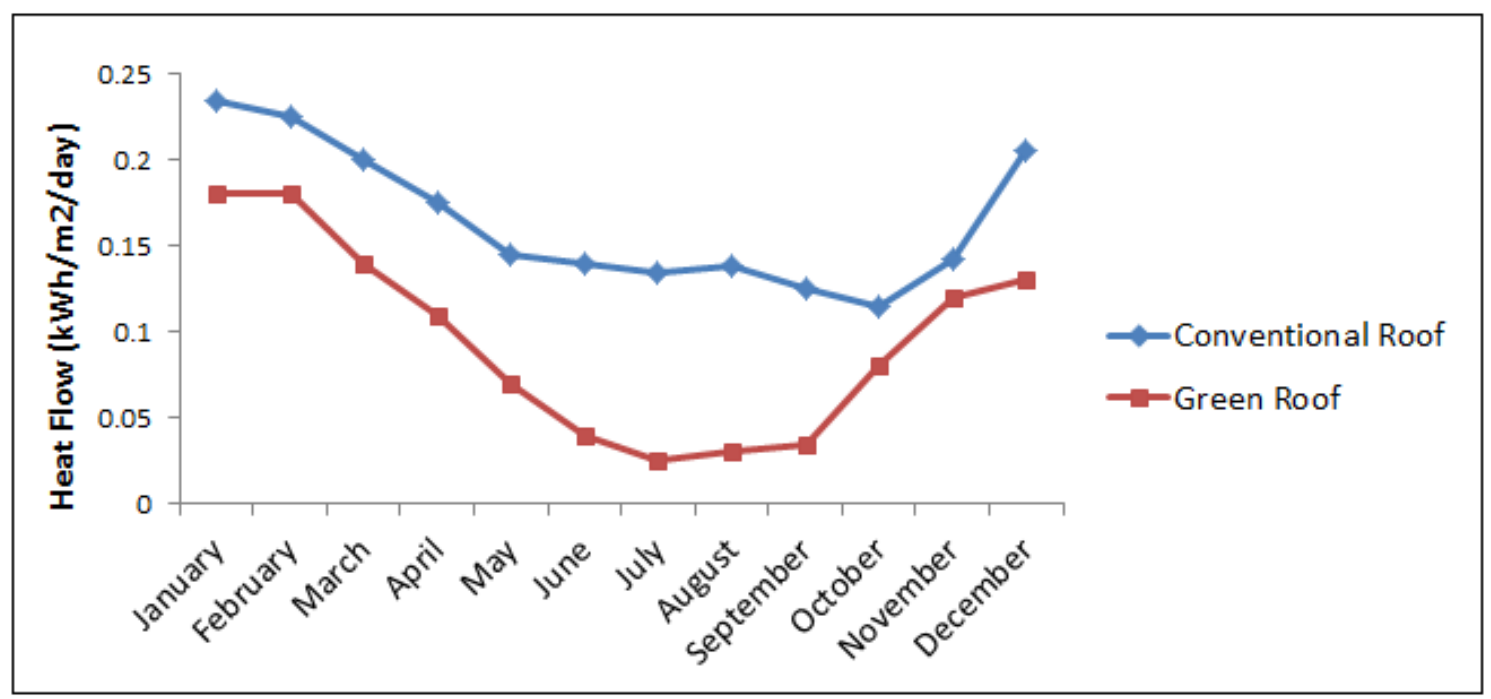

Fig. 9 Comparison of the average daily heat flow through the green roofs and reference roof. Note Green Roof S has $7.5 \mathrm{~cm}$ of dark growth medium (Fig. 9 created using data from Lui and Minor, 2005).

In all, the reduction in energy demands was correlated to a reduction in the heat flux into and out of the building. The average green roof was able to reduce the heat flux by an average of $12-20 \%$ in the coldest months and reduce the heat flux by an average of $70-80 \%$ in the hottest months of summer (Fig 9). Sailor's model and 
others demonstrated that the heat flux of a typical extensive green roof could be improved through modification to the plant selection, the soil depth and irrigation schedule.

\section{Plant Selection}

Plants on a green roof influence many of the variables that contribute to the green roof's heat budget. One of those variables is the latent heat exchange, $Q(5)$, via condensation, evaporation and transpiration. These actions are influenced by the foliage height and leaf area index (LAI). The foliage height and LAI also directly influence heat convection, $Q(3)$, heat emittance $Q(4)$ and heat conduction or heat flux, $Q(7)$, by physically shading the surface of the roof (Fig. 10). A dense plant canopy is able to block $80-90 \%$ of the daily solar irradiance from reaching the soil layer (Tabares-Velasco and Srebric, 2009; Fioretti et al., 2010). The density of the canopy is related back to the foliage height through the assumption that a taller plant creates a dense canopy of many layers of leaves that can intercept the incoming radiation, $Q(1)$ and $Q(2)$. The height of the foliage also decreases the ambient air temperature within the canopy and boundary layer through evapotranspiration and shading, thereby decreasing the heat emitted by the roof and plants, $Q(4)$ and the heat transferred through the roof, $Q(7)$, (Fig. 11) (Del Barrio, 1997; Kumar and Kaushik, 2005). 


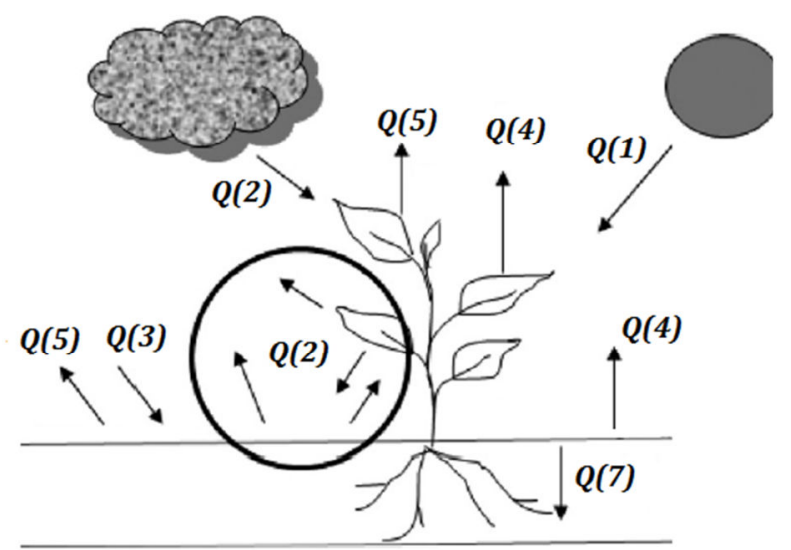

Fig. 10 The heat budget within the plant canopy on a green roof (Fig. 10 modified from Sailor, 2008)

Shading and evapotranspiration is also affected by the LAI. It varies between 0 for bare soil and 10 for dense conifer forests. Larger leaves, which have a higher LAI value, offer more shading and more surface area for evapotranspiration to take place (Fig 12). This in turn affects the heat flux; a higher LAI value decreases the heat flux through the roof (Fig. 13).

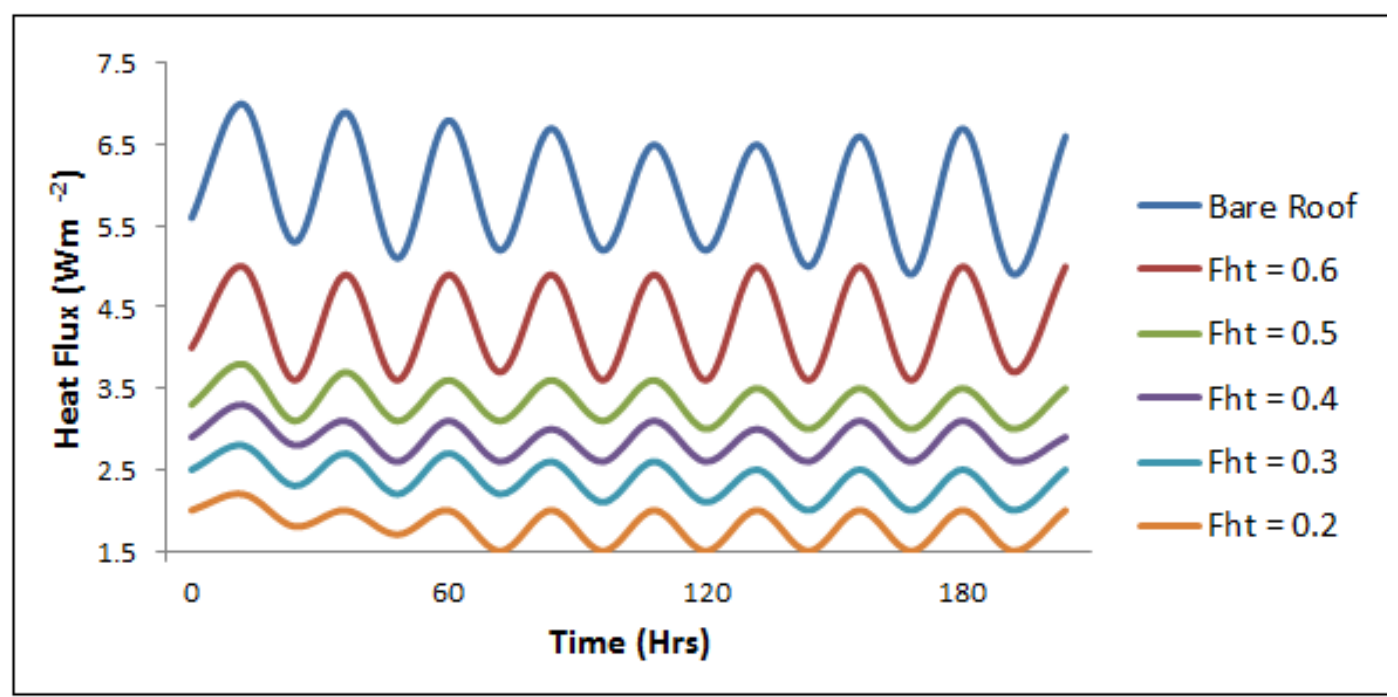

Fig. 11 Heat flux through roof for various foliage height, in meters, hich can also be described as the canopy thickness (Fig. 11 recreated from Kumar and Kaushik, 2005). 
The foliage height and the LAI are entirely dependent on the plant selection due to the wide variety of species that can be used on a green roof. The most prevalent species, Sedum can be as short as $1.5 \mathrm{~cm}$ or as tall as $20 \mathrm{~cm}$; but the most common size is $7.5 \mathrm{~cm}$ to $12 \mathrm{~cm}$. All species of sedum used have smaller leaves but form a dense ground cover. This is a critical characteristic because the plant canopy must cover the entire planting area for a green roof to function optimally. If there are bare spots devoid of plant material, these areas will function in a similar capacity as a conventional roof.

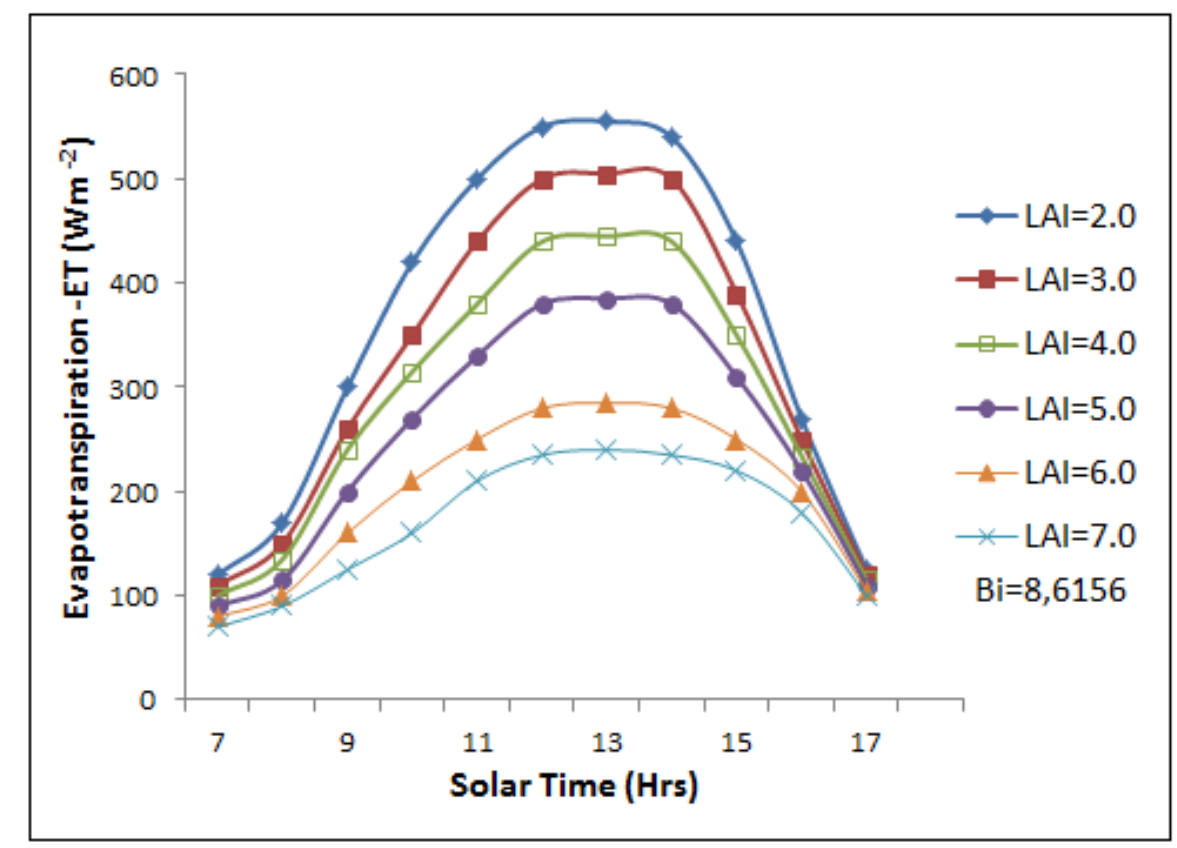

Fig. 12 Effect of Leaf Area Index (LAI) on diurnal variation of evapotranspiration (Fig. 12 recreated from Hodo-Abalo et al., 2012.).

Utilizing grasses and forbs on a green roof is also a possibility. These plant types come with a wide variety of leaf sizes and plant heights: $7.5 \mathrm{~cm}$ to $91 \mathrm{~cm}$. Both plant types will provide adequate cover and a moderate LAI value. However, the soil depth should be correlated to the height of the plant starting at a minimum of $6 \mathrm{~cm}$. 


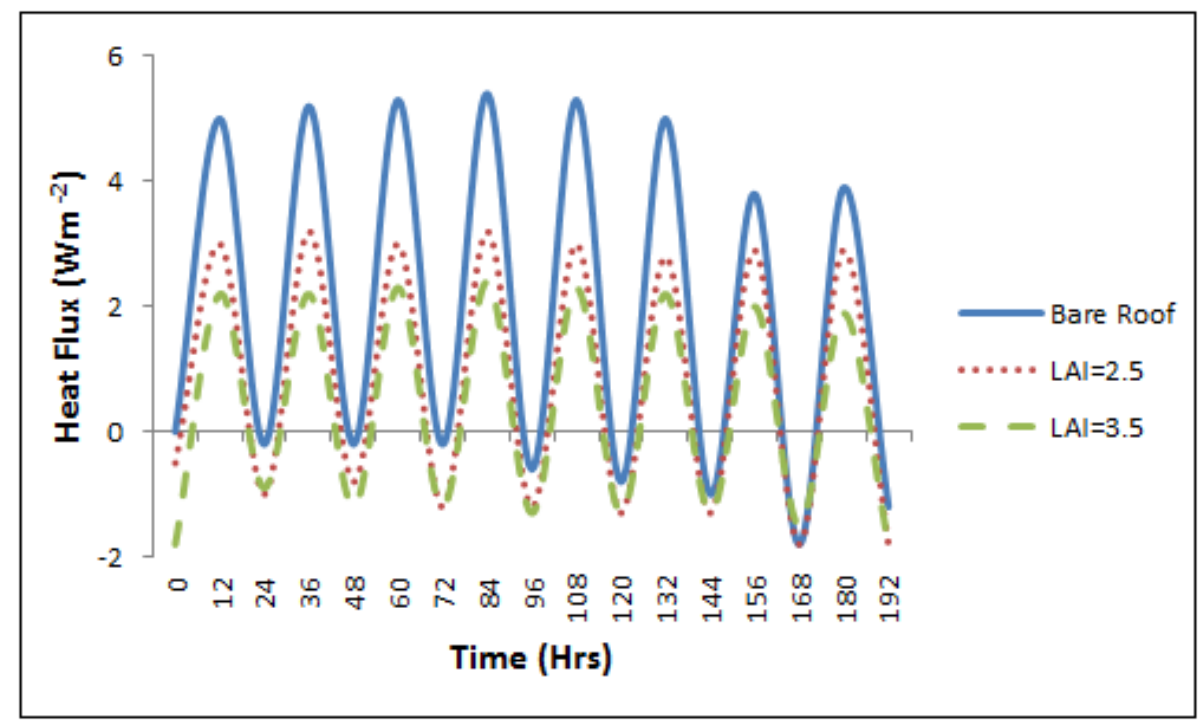

Fig. 13 Total heat flux through planted roof for various leaf area indices (Fig. 13 recreated from Kumar and Kaushik, 2005).

Just as in the summer, in the winter the foliage height and LAI determine the amount of heat flux through the roof. In the winter, the dormant plants still act to help insulate the roof. They do this by reducing the velocity of the cold wind over the roof. The degree of protection that the plants offer depends on the height and surface texture of the dead plant material (DOE, 2004). However, the higher LAI values in the winter can be detrimental to the amount of short and long wave irradiance, $Q(1)$ and $Q(2)$, that can reach the soil layer to heat it. This energy could have then passed through the roof to the building interior below. An example of this problem is found in Sailor's 2008 research; when the LAI was increased from the original value of 2 to 5 , the annual energy consumption for each city was lower (Fig. 14). However, the higher value for LAI increased the demand for natural gas in Chicago in the colder winter months over the green roof with the lower LAI value; 
Houston saw very little difference between the demands for natural gas in any season.
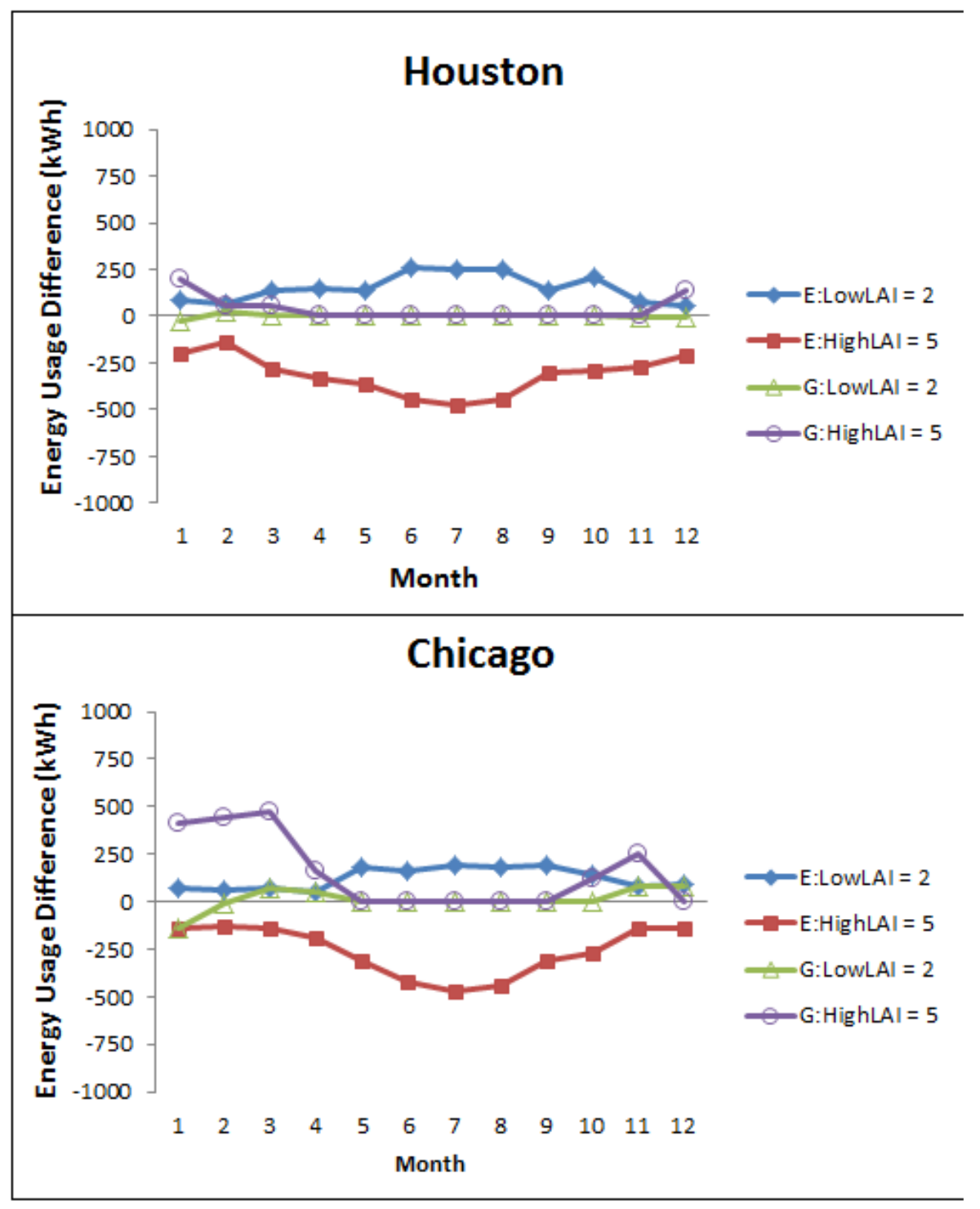

Fig. 14 Difference in monthly energy use (E: electricity; G: natural gas) for a green roof with differing LAI as compared to a baseline green roof in Houston and Chicago. LAI: baseline=2; low=1; high=5 (Fig. 14 recreated from Sailor, 2008). 


\section{Soil Depth}

Just as the soil depth dictates the plant selection, it also controls the heat conduction, $Q(7)$, on a green roof (Fig. 15). Deeper soil depths, such as those over 6 $\mathrm{cm}$, are able to maintain a more even temperature distribution through the day and night by minimizing the fluctuations of the membrane temperature (Boivin et al., 2001). The same is true of deeper soils on a seasonal basis (Getter and Rowe, 2009). This effect is due to the soil and layers of air between the soil and membrane providing a thermal resistance to heat flux into or out of the building interior (Teemusk and Mander, 2010). Altogether, the layers of soil and air on a green roof can provide an additional 30\% R-value insulation rating when compared to a conventional roof (Pierre et al., 2010).

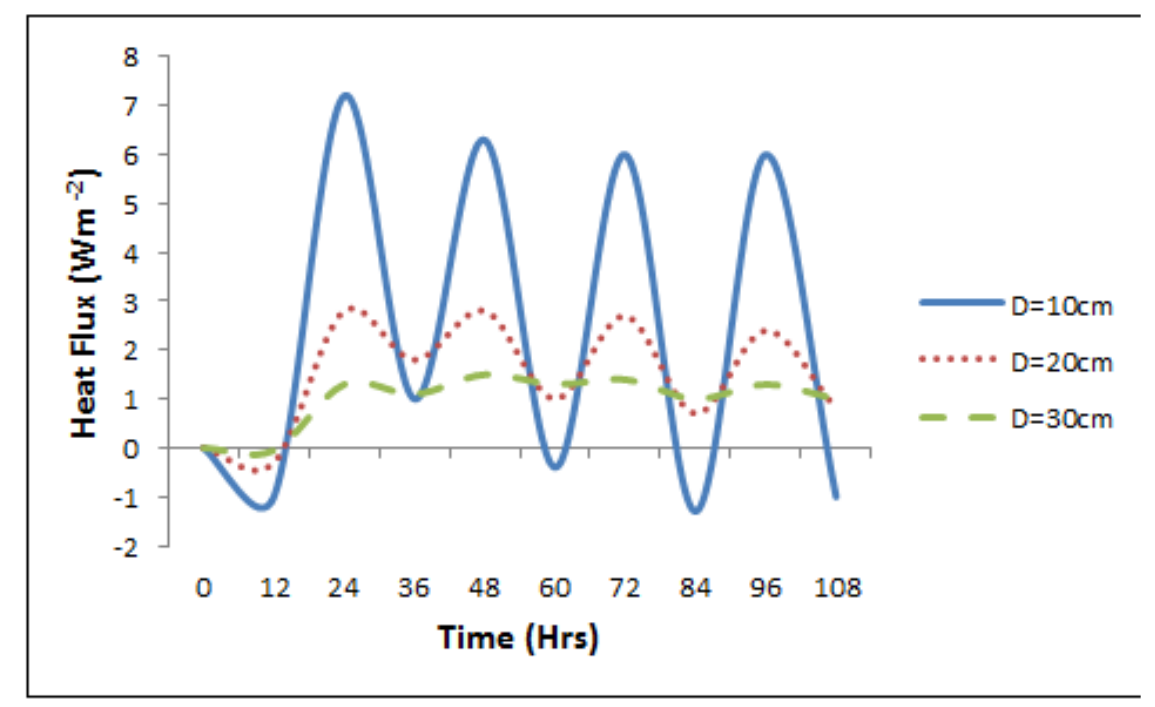

Fig. 15 Effect of the thickness of the soil layer (D) on the heat flux through the roof; LAI=5 (Fig. 15 recreated from Del Barrio, 1998)

Deeper soils are also able to maintain a higher volumetric moisture level to aid cooling the roof in the summer through latent heat exchange, $Q(5)$. This is especially 
true for green roofs with a regular watering schedule. The evaporation rates are highest on the day of the watering event with the rate declining as more time elapses from the watering event (Dewey et al., 2004). However, the deeper the soil, the longer the plants and soil were able to maintain a high evapotranspiration rate after a watering event (VanWoert et al., 2005b).

This benefit can mean a significant energy savings for areas with a temperate climate. Sailor's 2008 study confirmed that increasing the soil depth could affect the demand for natural gas in the winter and electricity in the summer (Fig. 16). For each $10 \mathrm{~cm}$ of soil added, the annual demand for natural gas decreased by $0.65 \%$ and $0.93 \%$ in Chicago and Houston respectively (Sailor, 2008). However, the additional soil depth created only a $0.01 \%$ reduction in the annual electricity load for each city (Sailor, 2008). 


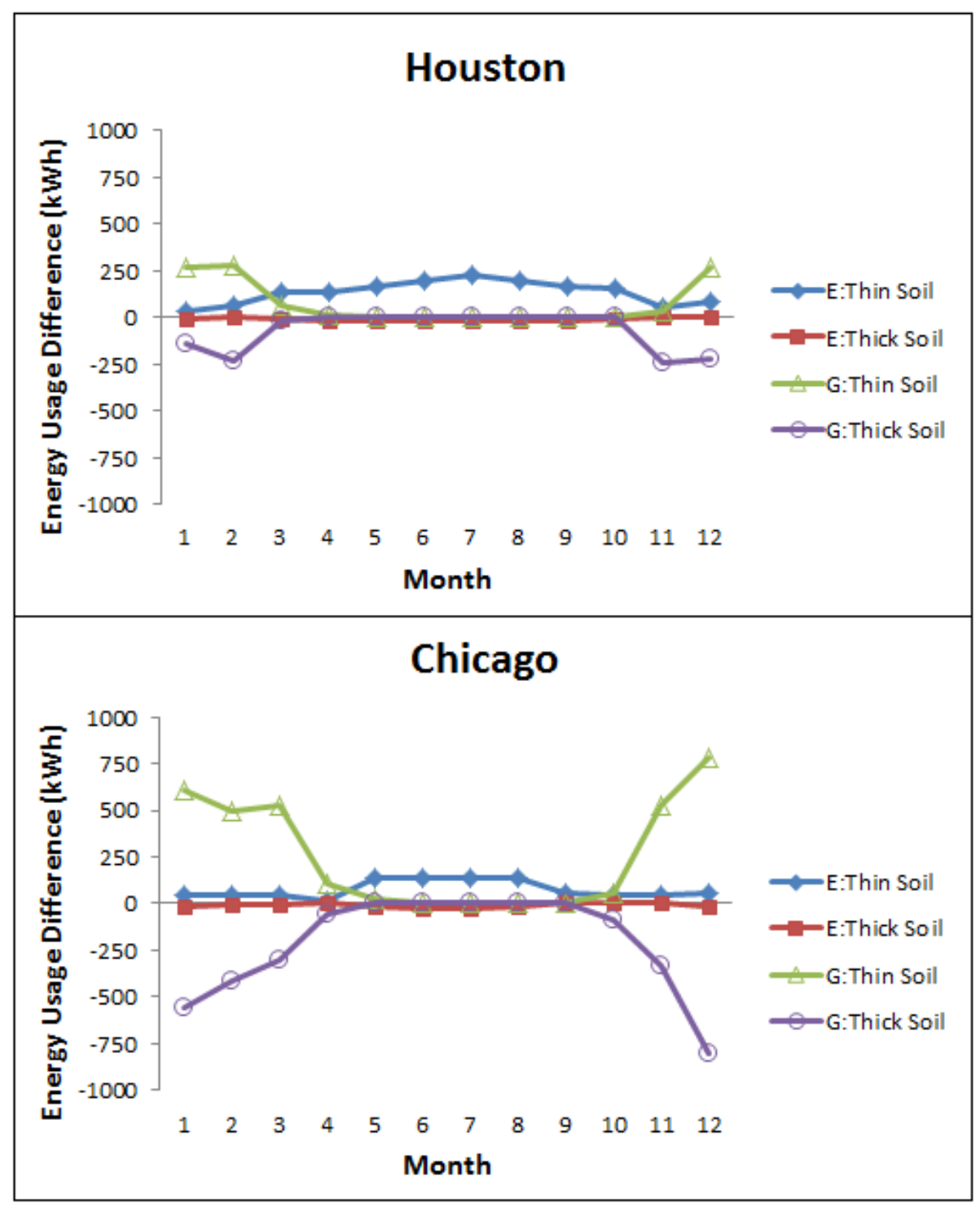

Fig. 16 Difference in monthly energy use (E: electricity; G: natural gas) for a green roof with differing soil depths as compared to a baseline green roof in Houston and Chicago. Soil depths: baseline $=20 \mathrm{~cm}$; thin soil $=10 \mathrm{~cm}$; thick soil $=30$ cm (Fig. 16 recreated from Sailor, 2008).

\section{Irrigation}

The soil volumetric moisture content on a green roof provides a positive feedback into the latent heat exchange, $Q(5)$. The moisture can originate from either a rain event or irrigation. The moisture availability directly affects the latent heat 
exchange through evapotranspiration of the plants and evaporation from the soil. The greater soil volumetric moisture content can effectively cool a green roof's soil layer as much as $7^{\circ} \mathrm{C}$ in the summer (Price et al., 2011), thereby reducing the heat flux through the roof (Fig. 17).

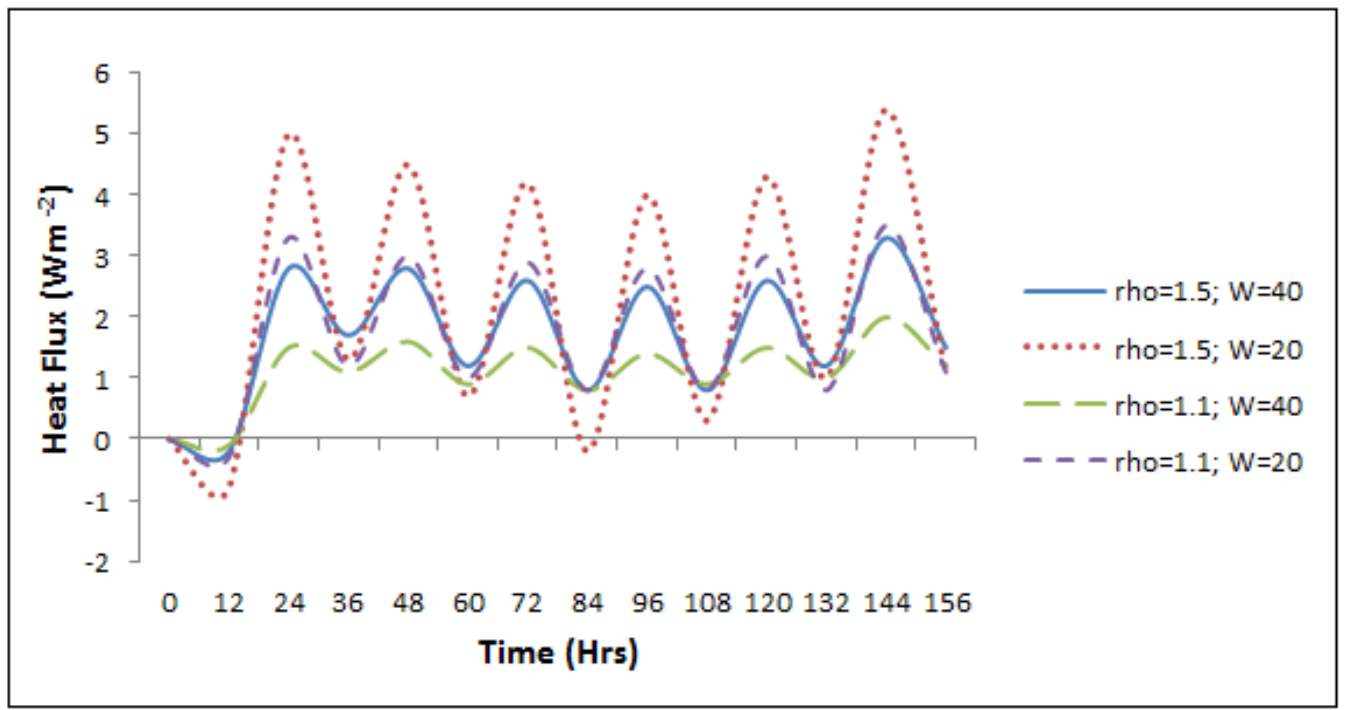

Fig. 17 Effect of the soil volumetric moisture content (W) on the heat flux through the roof with varying soil densities (rho 1.1=1100 $\mathrm{kg} \mathrm{m}^{-3}$; rho $1.5=1500 \mathrm{~kg} \mathrm{~m}^{-3}$ ); LAI=5 (Fig. 17 recreated from Del Barrio, 1998)

In comparison to the plant selection and soil depth, irrigation by itself does not greatly affect the natural gas or electrical demands of the buildings in the summer (Fig. 18). 


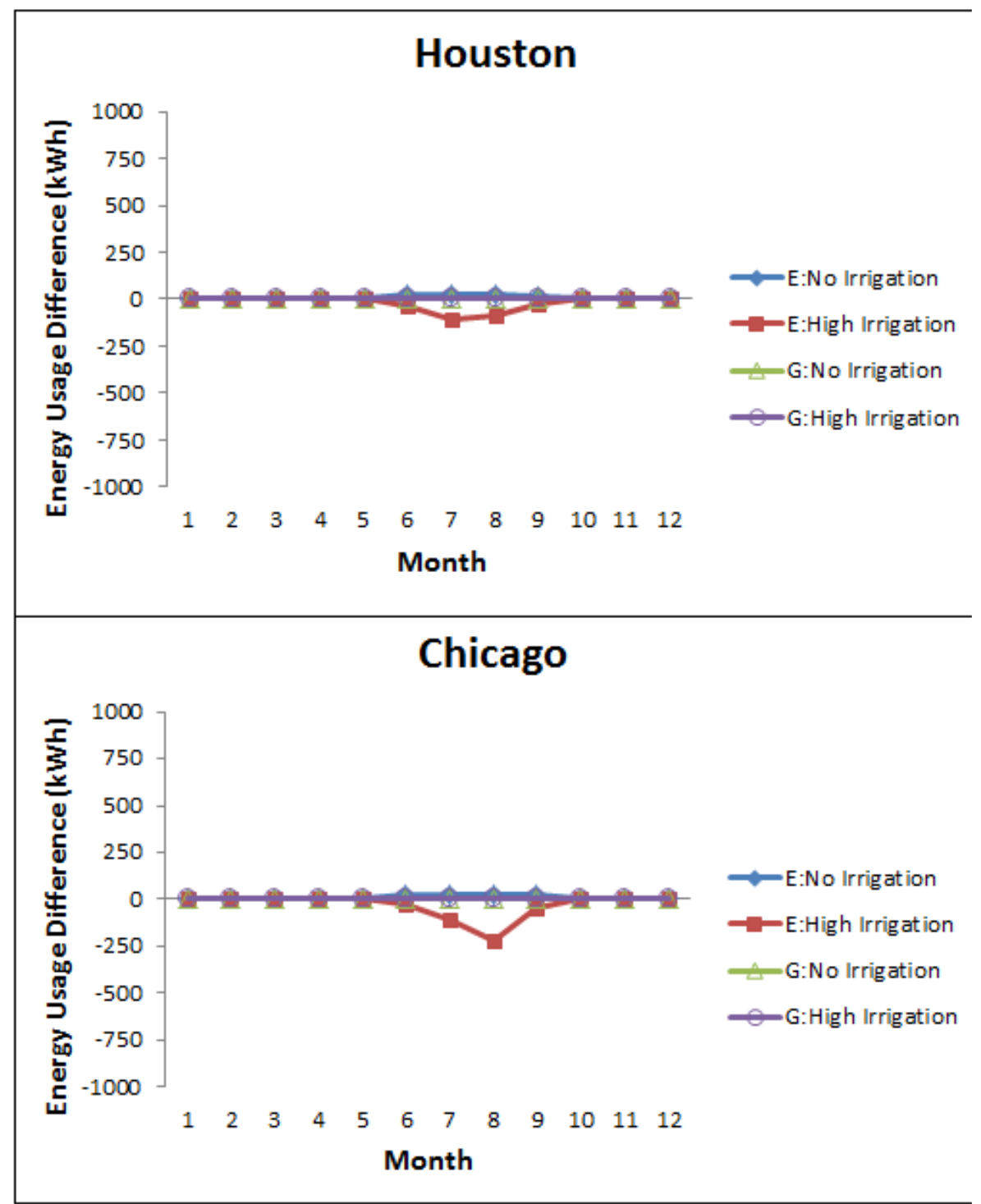

Fig. 18 Difference in monthly energy use (E: electricity; G: natural gas) for a green roof with irrigation schedules as compared to a baseline green roof in Houston and Chicago. Irrigation schedule (cm/week): no irrigation=0; high irrigation $=2$ (Fig. 18 recreated from Sailor, 2008).

\section{Comparison of $\mathrm{CO}_{2}$ Emissions for Commercial Buildings}

The average $\mathrm{CO}_{2}$ emitted to heat and cool a building with a conventional roof is 0.62

$\mathrm{kg} \mathrm{CO}_{2} \mathrm{~m}^{-2} \mathrm{yr}^{-1}$. When the $\mathrm{CO}_{2}$ emissions are combined for all commercial building stock in the United States, the $\mathrm{CO}_{2}$ emissions are $3.73 \times 10^{11} \mathrm{~kg} \mathrm{CO}_{2} \mathrm{~m}^{-2} \mathrm{yr}^{-1}$. The 
green roof reduces these emissions rates by $7.6 \%$ (Table 6). The savings are also calculated for several other scenarios with changes in plant selection, soil depth and irrigation (Tables 7-10).

Table $6 \mathrm{CO}_{2}$ emissions on a baseline green roof compared to the $\mathrm{CO}_{2}$ emissions for a conventional roof in the commercial sector. (Soil Depth $=20 \mathrm{~cm}$; Irrigation= $1 \mathrm{~cm}$ per week; LAI=2)

\begin{tabular}{|c|c|c|c|c|}
\hline \multirow[t]{2}{*}{ Use } & $\begin{array}{c}\text { Conventional } \\
\text { Roof } \\
\end{array}$ & $\begin{array}{c}\text { Baseline Green } \\
\text { Roof }\end{array}$ & $\begin{array}{l}\text { CO2 Emission } \\
\text { Savings }\end{array}$ & $\begin{array}{c}\text { \% Reduction } \\
\text { CO2 Emissions } \\
\text { per year }\end{array}$ \\
\hline & kg CO2 m-2 yr-1 & kg CO2 m-2 yr-1 & kg CO2 m-2 yr-1 & \\
\hline \multicolumn{5}{|l|}{ Electric } \\
\hline Heating & 0.06 & 0.05 & 0.00 & 4.5 \\
\hline Cooling & 0.16 & 0.15 & 0.01 & 4.5 \\
\hline \multicolumn{5}{|c|}{ Natural Gas } \\
\hline Heating & 0.40 & 0.36 & 0.04 & 10.0 \\
\hline $\begin{array}{l}\text { Total for } \\
\text { Heating } \\
\text { and } \\
\text { Cooling }\end{array}$ & 0.62 & 0.57 & -0.19 & 7.6 \\
\hline
\end{tabular}

(Table compiled from information from: Hong and Slatick, 1994; EIA, 2006; Sailor, 2008; EIA, 2010a; EIA, 2011a EIA, 2011b) 
Table $7 \mathrm{CO}_{2}$ emissions on green roof with an $\mathrm{LAI}$ increased by three compared to the $\mathrm{CO}_{2}$ emissions for a conventional roof in the commercial sector. (Soil Depth=20 cm; Irrigation $=1 \mathrm{~cm}$ per week; $\mathrm{LAI}=5$ )

\begin{tabular}{|c|c|c|c|c|}
\hline \multirow[t]{2}{*}{ Use } & $\begin{array}{c}\text { Conventional } \\
\text { Roof }\end{array}$ & $\begin{array}{l}\text { Green Roof w/ } \\
\text { Increase of LAI } \\
\text { by } 3\end{array}$ & $\begin{array}{c}\text { CO2 Emission } \\
\text { Savings }\end{array}$ & $\begin{array}{c}\text { \% Reduction } \\
\text { CO2 Emissions } \\
\text { per year }\end{array}$ \\
\hline & kg CO2 m-2 yr-1 & kg CO2 m-2 yr-1 & kg CO2 m-2 yr-1 & \\
\hline \multicolumn{5}{|l|}{ Electric } \\
\hline Heating & 0.06 & 0.05 & 0.00 & 5.4 \\
\hline Cooling & 0.16 & 0.15 & 0.01 & 5.4 \\
\hline \multicolumn{5}{|c|}{ Natural Gas } \\
\hline Heating & 0.40 & 0.37 & 0.03 & 8.6 \\
\hline $\begin{array}{l}\text { Total for } \\
\text { Heating } \\
\text { and } \\
\text { Cooling }\end{array}$ & 0.62 & 0.57 & 0.04 & 7.2 \\
\hline
\end{tabular}

(Table compiled from information from: Hong and Slatick, 1994; EIA, 2006; Sailor, 2008; EIA, 2010a; EIA, 2011a EIA, 2011b)

Table $8 \mathrm{CO}_{2}$ emissions on green roof with a thin layer of soil compared to the $\mathrm{CO}_{2}$ emissions for a conventional roof in the commercial sector. (Soil Depth $=10 \mathrm{~cm}$; Irrigation=1 $\mathrm{cm}$ per week; LAI=2)

\begin{tabular}{|c|c|c|c|c|}
\hline \multirow[t]{2}{*}{ Use } & $\begin{array}{c}\text { Conventional } \\
\text { Roof }\end{array}$ & $\begin{array}{c}\text { Green Roof w/ } \\
10 \mathrm{~cm} \text { Soil }\end{array}$ & $\begin{array}{l}\text { CO2 Emission } \\
\text { Savings }\end{array}$ & $\begin{array}{c}\text { \% Reduction } \\
\text { CO2 Emissions } \\
\text { per year }\end{array}$ \\
\hline & kg CO2 m-2 yr-1 & $\mathrm{kg} \mathrm{CO} 2 / \mathrm{m} 2$ & $\operatorname{kg~CO} 2$ m-2 yr-1 & \\
\hline \multicolumn{5}{|l|}{ Electric } \\
\hline Heating & 0.06 & 0.05 & 0.00 & 4.2 \\
\hline Cooling & 0.16 & 0.15 & 0.01 & 4.2 \\
\hline \multicolumn{5}{|c|}{ Natural Gas } \\
\hline Heating & 0.40 & 0.41 & -0.01 & 7.4 \\
\hline $\begin{array}{l}\text { Total for } \\
\text { Heating } \\
\text { and } \\
\text { Cooling }\end{array}$ & 0.62 & 0.62 & 0.00 & 6.0 \\
\hline
\end{tabular}

(Table compiled from information from: Hong and Slatick, 1994; EIA, 2006; Sailor, 2008; EIA, 2010a; EIA, 2011a EIA, 2011b) 
Table $9 \mathrm{CO}_{2}$ emissions on green roof with a thick layer of soil compared to the $\mathrm{CO}_{2}$ emissions for a conventional roof in the commercial sector. (Soil Depth $=30 \mathrm{~cm}$; Irrigation $=1 \mathrm{~cm}$ per week; LAI=2)

\begin{tabular}{|c|c|c|c|c|}
\hline \multirow[t]{2}{*}{ Use } & $\begin{array}{c}\text { Conventional } \\
\text { Roof }\end{array}$ & $\begin{array}{c}\text { Green Roof w/ } \\
30 \mathrm{~cm} \text { Soil }\end{array}$ & $\begin{array}{l}\text { CO2 Emission } \\
\text { Savings }\end{array}$ & $\begin{array}{c}\text { \% Reduction } \\
\text { CO2 Emissions } \\
\text { per year }\end{array}$ \\
\hline & kg CO2 m-2 yr-1 & kg CO2 m-2 yr-1 & kg CO2 m-2 yr-1 & \\
\hline \multicolumn{5}{|l|}{ Electric } \\
\hline Heating & 0.06 & 0.05 & 0.00 & 4.6 \\
\hline Cooling & 0.16 & 0.15 & 0.01 & 4.6 \\
\hline \multicolumn{5}{|c|}{ Natural Gas } \\
\hline Heating & 0.40 & 0.35 & 0.05 & 12.0 \\
\hline $\begin{array}{l}\text { Total for } \\
\text { Heating } \\
\text { and } \\
\text { Cooling }\end{array}$ & 0.62 & 0.56 & 0.06 & 8.8 \\
\hline
\end{tabular}

(Table compiled from information from: Hong and Slatick, 1994; EIA, 2006; Sailor, 2008; EIA, 2010a; EIA, 2011a EIA, 2011b)

Table $10 \mathrm{CO}_{2}$ emissions on green roof with additional irrigation compared to the $\mathrm{CO}_{2}$ emissions for a conventional roof in the commercial sector. (Soil Depth $=20 \mathrm{~cm}$; Irrigation $=2 \mathrm{~cm}$ per week; LAI=2)

\begin{tabular}{|c|c|c|c|c|}
\hline \multirow[t]{2}{*}{ Use } & $\begin{array}{c}\text { Conventional } \\
\text { Roof }\end{array}$ & $\begin{array}{c}\text { Green Roof w/ } 2 \\
\text { cm per week } \\
\text { irrigation }\end{array}$ & $\begin{array}{l}\text { CO2 Emission } \\
\text { Savings }\end{array}$ & $\begin{array}{l}\text { \% Reduction } \\
\text { CO2 Emissions } \\
\text { per year }\end{array}$ \\
\hline & $\operatorname{kg~CO} 2$ m-2 yr-1 & kg CO2 m-2 yr-1 & $\mathrm{kg} \mathrm{CO} 2 \mathrm{~m}-2$ yr-1 & \\
\hline \multicolumn{5}{|l|}{ Electric } \\
\hline Heating & 0.06 & 0.05 & 0.00 & 4.6 \\
\hline Cooling & 0.16 & 0.15 & 0.01 & 4.6 \\
\hline \multicolumn{5}{|c|}{ Natural Gas } \\
\hline Heating & 0.40 & 0.36 & 0.04 & 10.0 \\
\hline $\begin{array}{l}\text { Total for } \\
\text { Heating } \\
\text { and } \\
\text { Cooling }\end{array}$ & 0.62 & 0.57 & 0.05 & 7.6 \\
\hline
\end{tabular}

(Table compiled from information from: Hong and Slatick, 1994; EIA, 2006; Sailor, 2008; EIA, 2010a; EIA, 2011a EIA, 2011b)

\section{Discussion}

From the information above, the green roof holds potential in both carbon sequestration and reducing the demand for energy generated from the combustion 
of fossil fuels. Therefore, the amount of $\mathrm{CO}_{2}$ assimilated should be maximized when considering the argument that a green roof is an appropriate avenue to sequester carbon. The idea is similar if a green roof is the appropriate avenue to reduce the energy demand from fossil fuel combustion; the energy demand should be minimized. In order to achieve both avenues, the variables of plant selection, soil depth and irrigation should be the focus, as each variable is interrelated to the potential carbon offset of the roof.

To capitalize on the carbon sequestration potential of a green roof, it is necessary to maximize carbon assimilation, which characterizes the flux of carbon between the atmosphere and plants. The best option for maximizing carbon sequestration on a green roof would be to utilize plants types able to assimilate the most $\mathrm{CO}_{2}$ during the growing season. Using this line of thought, grasses and forbs would be the optimal choice. On average, grasses and forbs have the ability to assimilate approximately $90 \%$ more carbon annually than hardy succulents. Grasses and forbs are able to assimilate an average of $1.17 \mathrm{~kg} \mathrm{CO}_{2} \mathrm{~m}^{-2} \mathrm{yr}^{-1}$ (Table 3) whereas the hardy succulents assimilate $\mathrm{CO}_{2}$ at the average rate of $0.15 \mathrm{~kg} \mathrm{CO}_{2} \mathrm{~m}^{-2} \mathrm{yr}^{-1}$.

The plant type selected should also minimize the demand for energy from heating and cooling. The characteristic that is best able to minimize the energy demand is the LAI of the plants selected for a green roof. The LAI plays a large role in the thermal performance of a green roof through its effects on heat convection, $Q(3)$; 
heat emittance, $Q(4)$; latent heat exchange by evaporation, $Q(5)$; and heat conduction or heat flux, $Q(7)$. This benefit is true for both the summer and winter. In the summer, it is best to have a high LAI value (5 to 10 ). With a high LAI value, the plants provide the most shade to the soil so as to avoid the detrimental effects of high levels of heat convection (Theodosiu, 2003; Kumar and Kaushik, 2005; Sailor, 2008). This can reduce the conductive heat flux through the green roof by as much as $40-50 \%$ (Tabares-Velasco and Srebric, 2009). The larger LAI also provides ample surface area for latent heat exchange through evapotranspiration. By minimizing heat convection and maximizing latent heat exchange, the plant material reduces the amount of heat energy present to be transferred through the roof into the interior space.

A high value of LAI blocks incoming solar radiation from the soil in the summer, but in the winter, a high LAI value is detrimental; shading the soil decreases the convective heat energy transferred through the roof to help heat the interior. An example of the extent of the LAI's influence on energy demand is shown in Fig. 14. The roof with the higher LAI value requires more energy from electricity and natural gas for heating during the winter. The difference in the energy usage between green roofs with high/low LAI values can be as much as $555 \mathrm{kWh}$ per winter month. Therefore, to accommodate the optimum for all seasons, the LAI should be between 2 and 4, which would represent hardy succulents or forbs. Hardy succulents have a LAI that ranges from 1 to 4; with forbs the LAI range from 3 to 4; 
while grasses have a LAI of 4 to 8 (Mitchell et al., 1998; Han and Felker, 1997; WSU, 2008).

Based upon the evapotranspiration rates of the green roof planting, the best choice of plant type would be a combination of succulents, grasses and forbs. In combination, this mix of plant types has a greater evapotranspiration rate than any single group of plant types, which consequently results in a greater degree of latent heat exchange (Lundholm, 2010). The mix of plant types would also result in a LAI value within the desired range to minimize heat convection in the summer months, as well as maximize heat convection in the winter.

As stated above, a green roof with a deep layer of soil has a better thermal performance than a conventional roof. The soil layer provides insulation and protects the roof membrane from temperature fluctuations through its high thermal mass. The average $\mathrm{R}$-value for soil is $4.2 \times 10^{-1} \mathrm{~m}^{2}{ }^{\circ} \mathrm{C} \mathrm{W}^{-1}$ so that the soil is able to absorb the heat from the incoming radiation, $Q(1)$ and $Q(2)$, as well heat energy from the ambient air temperature, $Q(3)$, more slowly than the asphalt surface on a conventional roof. These details indicate that the soil is a moderately low conductor of energy, as it will store the energy it absorbs to releases it later in the day when the ambient air temperature is less than the temperature of the soil. With this thermal lag, the excess heat energy is not transmitted through the roof to the interior as it is with a conventional roof. 
Controlling for temperature fluctuations on the roof is beneficial year round. The control of those fluctuations in the summer is different from the control of those in the winter. The summer temperature fluctuations are affected by the amount of plant coverage. If the plant material is too sparse or non-existent, the soil is left unprotected from a high level of convective heating. In the winter, excess moisture levels negatively affect the temperature fluctuations by becoming a conduit for heat loss (Gedge and Firth, 2004; DOE, 2004). In both situations, the temperature fluctuations will closely follow the daily heating and cooling cycle similar to that of a conventional roof. Additionally, the magnitude of the energy transference of the green roof is similar to that of a conventional roof in both situations.

Moisture levels through rain events or irrigation also play an important role in reducing the $\mathrm{CO}_{2}$ emission on a green roof in the same fashion as the plant material; through latent heat exchange, $Q(5)$. The evaporation and transpiration responsible for the latent heat exchange come directly from the plants and the soil. In the summer, the evaporation and transpiration can be maximized through the use of irrigation. An additional centimeter of water per week can reduce $\mathrm{CO}_{2}$ emissions by an additional $1.5 \%$ when compared to a similar green roof with a less frequent watering schedule or less water volume. 
Looking at the reduction of electrical demands of heating and cooling, a green roof with a soil layer $20 \mathrm{~cm}$ thick will decrease the energy demand by $7.6 \%$ resulting in a $\mathrm{CO}_{2}$ emission savings of $0.05 \mathrm{~kg} \mathrm{CO}_{2} \mathrm{~m}^{-2} \mathrm{yr}^{-1}$ when compared to a conventional roof. The $\mathrm{CO}_{2}$ emission savings can increase to $0.06 \mathrm{~kg} \mathrm{CO}_{2} \mathrm{~m}^{-2} \mathrm{yr}^{-1}$ when the soil depth is increased to $30 \mathrm{~cm}$. However, it should be noted that the soil depth found on a typical extensive green roof $(2.5 \mathrm{~cm}$ to $10 \mathrm{~cm})$ has a similar thermal performance as that of a conventional roof. At this depth, the soil layer is not adequate to fully insulate the membrane from the energy flux through the roof to the building interior. The $\mathrm{CO}_{2}$ emissions between a conventional roof and a green roof with 10 $\mathrm{cm}$ of soil are the same when compared on a per square meter basis. Nevertheless, if compared on an average roof of $1,400 \mathrm{~m}^{2}$, the $\mathrm{CO}_{2}$ emission savings can be as much as $8.40 \times 10^{4} \mathrm{~kg} \mathrm{CO}_{2} \mathrm{yr}^{-1}$.

From the academic perspective, it is possible to reduce carbon dioxide emissions from electrical generation by a substantial amount by optimizing the variables of plant selection, soil depth and irrigation. The green roof design standards could be easily modified to reach the maximum on energy reduction: a mix of hardy succulents, grasses and forbs; the soil should be a minimum of $20 \mathrm{~cm}$ deep and the roof should be irrigated every two days for a total of $2 \mathrm{~cm}$ of water delivered per week during the growing season. 
Through this academic exercise, it is estimated that a green roof has the potential to mitigate up to $1.22 \mathrm{~kg} \mathrm{CO}_{2} \mathrm{~m}^{-2} \mathrm{yr}^{-1}$. This takes into account the $\mathrm{CO}_{2}$ assimilation of the plants and the $\mathrm{CO}_{2}$ reduction through decreased energy demands.

However, the green roof will only act as a carbon sink in the short term. The carbon stored within the plants' biomass will be released back into the atmosphere as respiration from decay (Jansson et al., 2010). The hardy succulents, grasses or forbs typically used on a green roof die annually and have low lignin content. The decay process will occur within a year or two. This short time period contrasts to the decades to centuries expected with other methods of carbon sequestration (Jansson et al., 2010). Therefore, an extensive green roof will not serve as a viable means for carbon sequestration.

The same can be said when looking at the green roof's potential for reducing $\mathrm{CO}_{2}$ emissions by reducing the heating and cooling energy demand. When looking at the real-world conditions beyond the academic exercise, the theory is misleading. By looking at the green roof as only a potential offset for carbon dioxide, there is a failure to see the green roof as a part of a larger system. For example, to see the true carbon offset potential of a green roof, there is a need to look at the green roof from a cradle-to-cradle perspective (McDonough and Braungart, 2002). This would include taking into account the carbon dioxide emitted from the materials used to construct the roof, primarily the concrete and steel, from their extraction, 
production, use and their reuse or shipment to the landfill. For the purposes of this commentary, the production is the only phase that will be highlighted for carbon dioxide emissions.

The production of concrete and steel/iron are two of the five primary industries that contribute to nearly one-quarter of the carbon dioxide emissions annually (Price et al., 2001; IEA, 2007). [The other three industries include chemicals, petroleum refining as well as pulp and paper production (Price et al., 2001).] For concrete, steel/iron production, the carbon dioxide emissions are generated primarily by the large amounts of energy used in the production of the final products. The additional carbon dioxide emissions are released during the calcination process of the raw materials during production (Hanle et al., 2004; EPA, 2012). The Environmental Protection Agency (EPA) estimates that $54.3 \mathrm{Tg} \mathrm{CO}_{2}$ equivalent were released during the production of steel and iron in the US in 2010; and that $30.5 \mathrm{Tg} \mathrm{CO}_{2}$ equivalent were released during the production of concrete in the US in 2010 (EPA, 2012). With large quantities of carbon released during the production of concrete and steel/iron, it is hard to conceive that a new commercial building with a green roof would provide a net-zero balance of carbon emissions over the 40 to 50 year life span of the roof (Gedge and Firth, 2004).

Additionally, the carbon-offset calculations for a green roof must also take into consideration the climate of the region in which the green roof is built. The 
estimation of $1.22 \mathrm{~kg} \mathrm{CO}_{2} \mathrm{~m}^{-2} \mathrm{yr}^{-1}$ is for a green roof under optimal conditions mixed plant types, deep soil and regular irrigation/watering cycle. This optimum green roof will not be possible in all metropolitan areas around the world. The primary design constraint will be the water availability in a region. As mentioned above, the variables of water, plant types and soil depth are interrelated to a point that changes to one, will cause changes to the others. Many of the green roofs studied in the referenced literature are located in Europe and western Canada. These areas can be described as Humid Subtropical Climate, Maritime Temperate Climates, Maritime Subarctic Climates or Humid Continental Climate per the Köppen Climate Classification System (McKnight and Hess, 2000). The commonality among all these climate regions is that the precipitation is relatively well distributed year round. The need for irrigation in these regions is limited and if the need does arise, there is an abundant supply of water to pull from. This is not the case for many metropolitan areas within the United States that are described as Dry Climates or those described meet the Köppen Dry-Summer Subtropical Climate due to the lack of rainfall in the summer months (McKnight and Hess, 2000). For these regions, a citywide installation of irrigated green roofs would not be a feasible solution to offsetting carbon dioxide emissions as it would have a detrimental effect on the water supply that may be in short supply.

Under these exceptions listed above, we can discount the prediction made by Getter and her colleagues; the large-scale implementation of green roofs could equal taking "approximately 10,000 midsized SUVs or trucks off the roadway" (Getter et al., 
2009). A green roof does not offer the long-term benefits of carbon sequestration or reduction in carbon dioxide emissions. As such, these claims should not be added to the list of evidence supporting the installation of green roofs. 


\section{References:}

Alexandri, E., Jones, P., 2007. Developing a one-dimensional heat and mass transfer algorithm for describing the effect of green roofs on the built environment: Comparison with experimental results. Building and Environment 42: 28352849.

Alexandri, E., Jones, P., 2008. Temperature decreases in an urban canyon due to green walls and green roofs in diverse climates. Building and Environment 43: 480-493.

ASHRAE Handbook : Fundamentals. 2009. [S.I.]: American Society of Heating, Refrigerating \& Air-Conditioning Engineers, Inc.

Banting, D., Doshi, H., Li, J., Missios, P., Au, A., Currie, B.A., Verrati, M. 2005. Report on the environmental benefits and costs of green roof technology for the City of Toronto prepared for City of Toronto and Ontario Centres of Excellence Earth and Environmental Technologies (OCE-ETech). October 31, 2005. Available from: http://www.toronto.ca/greenroofs/pdf/fullreport103105.pdf

Boddy, E., Hill, P.W., Farrar, J., Jones, D.L. 2007. Fast turnover of low molecular weight components of the dissolved organic carbon pool of temperate grassland field soils. Soil Biology \& Biochemistry 39: 827-835.

Borland, A.M., Maxwell, K., Griffiths, H. 2000. Ecophysiology of plants with Crassulacean acid metabolism. In: Leegood, R.C., Sharkey, T.D., Von Daemmerer, S. editors. Advances in Photosynthesis, Volume 9. Photosynthesis: Physiology and Metabolism. Secaucus, NJ: Kluwer Academic Publishers. 593p.

Boivin, M.A., Lamy, M.P., Gosselin, A., Dansereau, B. 2001. Effect of artificial substrate depth on freezing injury of six herbaceous perennials grown in a green roof system. Horttechnology 11: 409-412.

Buis, G.M., Blair, J.M., Burkepile, D.E., Burns, C.E., Chamberlain, A.J., Chapman, P.L., Collins, S.L., Fynn, R.W.S., Govender, N., Kirkman, K.P., Smith, M.D., Knapp, A.K. 2009. Controls of aboveground net primary production in mesic savanna grasslands: an inter-hemispheric comparison. Ecosystems 12:982-995.

Burgess, H., 2004. An assessment of the potential of green roofs for bird conservation in the UK. Submitted for the assessment of BSc Hons Geography, University of Sussex. May 2004. 
Carter, T., Keeler, A. 2008 Life-cycle cost-benefit analysis of extensive vegetated roof systems. Journal of Environmental Management 87:350-363.

Coffman, R.R., Waite, T. 2006. Vegetated roofs as reconciled habitats: rapid assays beyond mere species counts. Urban Habitats 6. Available from: http://urbanhabitats.org/v06n01/vegetatedroofs_full.html

Connelly, M., Liu, K., Schaub, J. 2006. BCIT green roof research program, phase 1 summary of data analysis observation period - Jan. 1, 2005 to Dec. 31, 200". Centre for the Advancement of Green Roof Technology British Columbia Institute of Technology Report to Canada Mortgage and Housing Corporation.

Del Barrio, E.P. 1998. Analysis of the green roofs cooling potential in buildings. Energy and Buildings 27:179-193.

DOE - United States Department of Energy, Energy Efficiency and Renewable Energy. 2004. Federal energy management program - a new technology demonstration publication. Green roofs. DOE-EE0298. Available from: http://www1.eere.energy.gov/femp/pdfs/fta_green_roofs.pdf

Durhman, AK, Rowe, DB, Rugh, CL. 2006. Effect of watering regimen on chlorophyll fluorescence and growth of selected green roof plant taxa Hortscience 41: 1623-1628.

Durhman, A.K., Rowe, D.B., Rugh, C.L. 2007. Effect of substrate depth on initial growth, coverage, and survival of 25 succulent green roof plant taxa. Hortscience 42: 588-595.

EIA - United States Energy Information Administration. 2006. 2003 commercial buildings energy consumption survey detailed tables. Available from: http://www.eia.gov/emeu/cbecs/cbecs2003/detailed_tables_2003/detailed _tables_2003.html\#enduse03

EIA - United States Energy Information Administration. 2010a. Annual energy review 2009. DOE/EIA-0384(2009). Available from: http://www.eia.doe.gov/emeu/aer/contents.html

EIA - United States Energy Information Administration. 2010b. International energy outlook 2010. DOE/EIA-0484(2010). Available from:

http://www.eia.gov/oiaf/ieo/index.html

EIA - United States Energy Information Administration. 2011a. Annual energy outlook 2011 early release overview. DOE/EIA-0383ER (2011). Available from: http://www.eia.doe.gov/forecasts/aeo/ 
EIA - United States Energy Information Administration. 2011b. Electric power annual 2009, Revised January 2011. DOE/EIA-0348(2009). Available from: http://www.eia.gov/cneaf/electricity/epa/epa_sum.html

Emilsson, T. 2005. Extensive vegetated roofs in Sweden establishment, development and environmental quality. Doctoral thesis. Swedish University of Agricultural Sciences Uppsala.

Emory Knoll Farms green roof catalog. 2011. Available from: http://www.greenroofplants.com/catalog/plant-catalog/

EPA - United States Environmental Protection Agency. 2003. Cooling summertime temperatures-strategies to reduce heat island effects.

EPA - United States Environmental Protection Agency. 2010. 2008 Progress report vehicle and engine compliance activities. EPA-420-R-10-022. Available from: http://www.epa.gov/oms/about/420r10022.pdf

EPA - United States Environmental Protection Agency. 2012. Inventory of U.S. greenhouse gas emissions and sinks: 1990-2010. EPA 430-R-12-001. Available from: http://www.epa.gov/climatechange/Downloads/ghgemissions/US-GHGInventory-2012-Main-Text.pdf

Etera green roof plant catalog. 2011. Available from: http://etera.com/products/varieties.aspx?

Fields. 2003. Fields company roofing and waterproofing products. Available from: http://fieldscorp.com/commercial/BURsystems/design/roof_decks1.html

Fioretti, R., Palla, A., Lanza, L.G., Principi, P. 2010. Green roof energy and water related performance in the Mediterranean climate. Building and Environment 45:1890-1904.

Fisher, J. 2003. Energy density of coal. The physics factbook. Available from: http://hypertextbook.com/facts/2003/JuliyaFisher.shtml.

Gedge, D., Firth, M. 2004. Green roofs: Benefits and cost implications. A report for Sustainable Eastside.

Gedge, D., Kadas, G. 2005. Green roofs and biodiversity. Biologist. 52: 161-169 
Getter, K.L., Rowe, D.B. 2009. Substrate depth influences sedum plant community on a green roof. Hortscience 44: 401-407.

Getter, K.L., Rowe, D.B., Robertson, G.P., Cregg, B.M., Andresen, J.A. 2009. Carbon sequestration potential of extensive green roofs. Environmental Science Technology 43: 7564-7570.

Gibson, D. J. 2009. Grasses and grassland ecology. Oxford: Oxford University Press. $134 p$.

Grant, G. 2006. Extensive green roofs in London. Urban Habitats. 4: 51-65. Available from: http://urbanhabitats.org/v04n01/london_pdf.pdf

Gravatt, D.A., Martin, C.E. 1992. Comparative ecophysiology of 5 species of sedum (Crassulaceae) under well-watered and drought-stressed conditions. Oecologia 92: 532-541.

Güerere, I., Tezara, W., Herrera, C., Fernandez, M.D., Herrera, A. 1996. Recycling of $\mathrm{CO}_{2}$ during induction of CAM by drought in Talinum paniculatum (Portulacaceae). Physiologia Plantarum 98: 471-476.

Gurevitch, J. 1992. Differences in photosynthetic rate in populations of Achillea lanulosa from two altitudes. Functional Ecology 6:568-574.

Han, H., Felker, P. 1997. Field validation of water-use efficiency of the CAM plant Opuntia ellisiana in south Texas. Journal of Arid Environments. 36: 133-148.

Hanle, L.J., Jayaraman, K.R., Smith, J.S. 2004. $\mathrm{CO}_{2}$ emissions profile of the U.S. cement industry. Available from: www.epa.gov/ttnchie1/conference/ei13/ghg/hanle.pdf

Hardy, S. 1997. Time-saver details for roof design. McGraw-Hill New York. 49-65, 89, 115-135p.

Harris, F.S., Martin, CE. 1991. Correlation between cam-cycling and photosynthetic gas-exchange in 5 species of Talinum (Portulacaceae). Plant Physiology 96: 1118-1124.

Herrera, A. 2009. Crassulacean acid metabolism and fitness under water deficit stress: if not for carbon gain, what is facultative CAM good for? Annals of Botany 103: 645-653. 
Hodo-Abalo, S., Banna, M., Zeghmati, B. 2012. Performance analysis of a planted roof as a passive cooling technique in hot-humid tropics. Renewable Energy 39: 140-148.

Hong, B.D., Slatick, E.R. 1994. Carbon dioxide emission factors for coal. Quarterly Coal Report. DOE/EIA-0121(94/Q1).

Ibrahim, D.G., Gilbert, M.E., Ripley, B.S., Osborne, C.P. 2008. Seasonal differences in photosynthesis between the C3 and C4 subspecies of Allotropies semialata are offset by frost and drought. Plant, Cell and Environment 31:1038-1050.

IEA - International Energy Agency. 2007. Tracking industrial energy efficiency and $\mathrm{CO}_{2}$ emissions. Available from: http://www.iea.org/Textbase/npsum/tracking2007SUM.pdf

Jacobs, P.A. 2006. Theory of heat and mass transfer. Bellingham, WA. Available from: http://link.aip.org/link/doi/10.1117/3.651915.ch4

Kadas, G. 2006. Rare invertebrates colonizing green roofs in London". Urban Habitats 4: 66-86. Available from: http://urbanhabitats.org/v04n01/invertebrates_full.html\#cite7

Kaska, O., Yumrutas, R. 2009. Experimental investigation for total equivalent temperature difference (TETD) values of building walls and flat roofs. Energy Conversion and Management 50: 2818-2825.

Klinkenborg, V. 2009. Up on the roof. National Geographic, 215(5): 84-103.

Köhler, Manfred. 2006. Long-Term Vegetation research on two extensive green roofs in Berlin. Urban Habitats 4: 3-26. Available from: http://urbanhabitats.org/v04n01/berlin_full.html

Kosareo, L., Ries, R. 2007. Comparative environmental life cycle assessments of green roofs. Building and Environment 42:2606-2613.

Kosny, J., Petrie, D., Gawin, P., Childs, P., Desjarlais, A., Christian, J. 2001. Thermal mass-energy savings potential in residential buildings. Oak Ridge National Labs. Available from: http://www.ornl.gov/sci/roofs+walls/research/detailed_papers/thermal/in dex.html

Kumar, R., Kaushik, S.C. 2005. Performance evaluation of green roof and shading for thermal protection of buildings. Building and Environment 40: 1505-1511. 
Levy, S.M. 2000. Building envelope and interior finishes databook. New York, NY McGraw Hill. 460p.

Liesecke, 1998. Water retention capacity of vegetated roofs. (Das retentionsvermogen von dachberrunungen) Stadt and Grun 47:46-53

Linder, E., Hoinkis, J. 2007. Chemie für Ingenieure. Wiley-VCH Verlag. 258p.

Liu, K. Baskaran, B. 2003. Thermal performance of green roofs through field evaluation. NRCC-46412. Proceedings from the First North American Green Roof Infrastructure Conference, Awards and Trade Show, Chicago, IL., May 29-30, 2003. 1-10p.

Liu K, Minor J. 2005. Performance evaluation of an extensive green roof. Paper presented at the Third Annual Greening Rooftops for Sustainable Communities Conference, Awards and Trade Show; 4-6 May 2005, Washington, DC.

Lundholm, J., MacIvor, J.S., MacDougall, Z., Ranalli, M. 2010. Plant species and functional group combinations affect green roof ecosystem functions. PLoS ONE: 5-3-e9677. Available from: http://www.plosone.org/article/info\%3Adoi\%2F10.1371\%2Fjournal.pone. 0009677

Martin, C.E., Higley, M., Wang, W.Z. 1988. Ecophysiological significance of $\mathrm{CO}_{2}$ recycling via Crassulacean acid metabolism in Talinum-calycinum engelm (Portulacaceae). Plant Physiology 86: 562-568.

Matteson, K.C. Langellotto, G.A. 2008. Determinates of inner city butterfly and bee species richness. Annals of the Entomological Society of America. 101: 140150.

McDonough, W., Braungart. M. 2002. Cradle to cradle: remaking the way we make things. New York: North Point Press.

McKnight, T. L., Hess, D. 2000. Climate zones and types. Physical geography: A landscape appreciation. New Jersy: Prentice Hall.

Mitchell, R.B., Moser, L.E., Moore, K.J., Redfearn, D.D. 1998. Tiller demographics and leaf area index of four perennial pasture grasses. Agronomy Journal 1998 90: 47-53.

Mothersplants Green Roof Plant Catalog. 2011. Available from: http://www.motherplants.net/ 
NAS - United States National Academy of Sciences. 2008. Understanding and responding to climate change. Available from:

http://americasclimatechoices.org/climate_change_2008_final.pdf.

Nat's Nursery living roofs catalog. 2011. Available from: http://www.natsnursery.com/Living_Roof_Plants.php

Natural Gas.org. Electric generation using natural gas. 2010. http://naturalgas.org/overview/uses_eletrical.asp

Niachou, A., Papakonstantinou, K., Santamouris, M., Tsangrassoulis, A., Mihalakakou, G. 2001. Analysis of the green roof thermal properties and investigation of its energy performance. Energy and Buildings 33: 719-729.

Oberndorfer, E., Lundholm, J., Bass, B., Coffman, R.R., Doshi, H., Dunnett, N., Gaffin, S., Kohler, M., Liu, K.K.Y., Rowe, B. 2007. Green roofs as urban ecosystems: Ecological structures, functions, and services. Bioscience 57: 823-833.

ORNL - Oak Ridge National Laboratory. Energy units. Date Unknown. Available from: http://bioenergy.ornl.gov/papers/misc/energy_conv.html

Ouldboukhitine, S.E., Belarbi, R., Jaffal, I., Trabelsi, A. 2011. Assessment of green roof thermal behavior: A coupled heat and mass transfer model. Building and Environment 46: 2624-2631.

Pierre, J., Bisby, L., Anderson, B., MacDougall, C. 2010. Thermal performance of green roof panels in sub-zero temperatures. Journal of Green Building 5: 91104.

Pilon-Smits, E.A.H., Hart, H.T., VanBrederode, J. 1991. Seasonal-variation of phosphoenolpyruvate carboxylase specific activity in 15 species exhibiting facultative or obligate crassulacean acid metabolism. Journal of Plant Physiology 138: 581-586.

Piotrowicz, L.M. and Osgood, S. 2010. Building science 101: a primer for librarians. American Library Association Chicago. 110-111p.

Pon, B. 1999. "Pavement Albedo". Heat island group. Available from: http://eetd.lbl.gov/HeatIsland/Pavements/Albedo

Price, J.G., Watts, S.A., Wright, A.N., Peters, R.W., Kirby, J.T. 2011. Irrigation lowers substrate temperature and enhances survival of plants on green roofs in the southeastern United States. Horttechnology 21: 586-592. 
Price, L., Sinton, J., Worrell, E., Phylipsen, D., Huc, X., Li, J. 2002. Energy use and carbon dioxide emissions from steel production in China. Energy 27: 429446.

Reich, P.B., Buschena, C., Tjoelker, M.G., Wrage, K., Knops, J., Tilman, D., Machado, J.L. 2003. Variation in growth rate and ecophysiology among 34 grassland and savanna species under contrasting $\mathrm{N}$ supply: a test of functional group differences. New Phytologist 157:617-631.

Retzlaff, W., Ebbs, S., Alsup, S., Morgan, S., Woods, E., Jost, V., Luckett, K. 2008. What is that running off of my green roof? Session 3.1: Runoff Quality and Quantity. Greening Rooftops for Sustainable Communities Conference, Awards and Trade Show, Baltimore MD. April 30-May 2, 2008.

Rolle, K. C. 2000. Heat and mass transfer. New Jersey: Prentice Hall.

Sailor, D.J. 2008. A green roof model for building energy simulation programs. Energy and Buildings 40: 1466-1478.

Saiz, S., Kennedy, C., Bass, B., Pressnail, K. 2006. Comparative life cycle assessments of standard and green roofs. Environmental Science \& Technology 40:43124316.

Santamouris, M., Pavlou, C., Doukas, P., Mihalakakou, G., Synnefa, A., Hatzibiros, A., Patargias, P. 2007. Investigating and analyzing the energy and environmental performance of an experimental green roof system installed in a nursery school building in Athens, Greece. Energy 32:1781-1788.

Sayed, O.H. 2001. Crassulacean acid metabolism 1975-2000, a check list. Photosynthetica 39: 339-352.

Schroll, E., Lambrinos, J.G., Sandrock, D. 2011. An Evaluation of plant selections and irrigation requirements for extensive green roofs in the Pacific Northwestern United States. Horttechnology 21: 314-322.

Shephelsky, K. 2002. Energy density of petroleum. The Physics Factbook. Available from: http://hypertextbook.com/facts/2002/KarolShepelsky.shtml

Skinner, C.J., 2006. Urban density. Meteorology and Rooftops Urban Policy and Research 24: 355-367.

Sonne, J. 2006. Evaluating green roof energy performance. ASHRAE Journal 48:5961. 
Subke, J.A., Tenhunen, J.D. 2004. Direct measurements of $\mathrm{CO}_{2}$ flux below a spruce forest canopy. Agricultural and Forest Meteorology 126: 157-168.

Szente, K., Nagy, Z., Takacs, Z., Csintalan, Z., Lichtenthaler, H.K., Tuba, Z. 1998. Limitations of net $\mathrm{CO}_{2}$ uptake in plant species of temperate dry loess grassland. Plant Physiology and Biochemistry 36: 753-758.

Tabares-Velasco, P. C., Srebric, J. 2009. The role of plants in the reduction of heat flux through green roofs: laboratory experiments. ASHRAE Transactions 115: 793-802.

Teach Coal: American Coal Foundation. 2010. Lesson Plans grade level 4-8. How much does it cost to light your school? Available from: http://www.teachcoal.org/lessonplans/how_much.html

Teemusk, A., Mander, U. 2010. Temperature regime of planted roofs compared with conventional roofing Systems. Ecological Engineering 36: 91-95.

Urban, O., Ac, A., Kalina, J., Priwitzer, T., Sprtova, M., Spunda, V., Marek, M.V. 2007. Temperature dependences of carbon assimilation processes in four dominant species from mountain grassland ecosystem. Photosynthetica 45: 392-399.

VanWoert, N.D., Rowe, D.B., Andresen, J.A., Rugh, C.L., Fernandez, R.T., Xiao, L. 2005a. Green roof stormwater retention; effects of roof surface, slope and media depth. Journal of Environmental Quality 34:1036-1044.

VanWoert, N.D., Rowe, D.B., Andresen, J.A., Rugh, C.L., Xiao, L. 2005b. Watering regime and green roof substrate design affect Sedum plant growth. Hortscience 40: 659-664.

Waldbaum, Hanna. 2008. Green roofs for urban agriculture: What is required to support their implementation in the UK? MS Architecture: Advanced Environmental and Energy Studies. University of East London.

Wong, N.H., Tay, S.F., Wong, R., Ong, C.L., Sia, A. 2003a. Life cycle cost analysis of rooftop gardens in Singapore. Building and Environment 38:499-509.

Wong, N.H., Cheong, D.K.W., Yan, H., Soh, J., Ong, C.L., Sia, A. 2003b. The effects of rooftop garden on energy consumption of a commercial building in Singapore. Energy and Buildings 35:353-364. 
White, J.W., Snodgrass, E. 2003. Extensive green roof plant selection and characteristics. Proc. of 1st North American Green Roof Conference: Greening rooftops for sustainable communities, Chicago. 29-30 May 2003. The Cardinal Group, Toronto. 166-176p.

WSU - 2008. Department of Biological Systems Engineering at Washington State University. 2008. Crop Leaf Parameters. Available from: http://www.bsyse.wsu.edu/cs_suite/cropsyst/crop_editor/manual/leaf.htm

Yan, J. 2004. Energy density of natural gas. The physics factbook. Available from: http://hypertextbook.com/facts/2004/JessicaYan.shtml 


\section{Appendix A}

Plant List for Green Roofs within a Temperate Climate

\begin{tabular}{|c|c|c|c|}
\hline Family & Scientific Name & Vegetation Type & $\begin{array}{c}\text { Hardiness } \\
\text { Zone } \\
\text { (Upper Limit) }\end{array}$ \\
\hline \multirow{9}{*}{ Aizoaceae } & Delosperma ashtonii & Hardy Succulent & 6 \\
\hline & Delosperma basuticum & Hardy Succulent & 6 \\
\hline & Delosperma cooperi & Hardy Succulent & 6 \\
\hline & Delosperma dyeri & Hardy Succulent & 6 \\
\hline & Delosperma ecklonis & Hardy Succulent & 6 \\
\hline & Delosperma kelaidis & Hardy Succulent & 6 \\
\hline & Delosperma nubigenum & Hardy Succulent & 5 \\
\hline & Delosperma ssp. var. & Hardy Succulent & 5 \\
\hline & Malephora crocea & Tender Succulent & 8 \\
\hline \multirow{4}{*}{ Alliaceae } & Allium cernuum & Forb & 4 \\
\hline & Allium schoenoprasum & Forb & 4 \\
\hline & Allium senescens & Forb & 4 \\
\hline & Allium ssp. var. & Forb & 4 \\
\hline \multirow{10}{*}{ Asteraceae } & Achillea millefolium & Forb & 3 \\
\hline & Achillea $x$ lewisii & Forb & 4 \\
\hline & Antennaria dioica & Forb & 3 \\
\hline & Artemisia stelleriana & Forb & 3 \\
\hline & Aster alpinus & Forb & 5 \\
\hline & Aster oblongifolius & Forb & 5 \\
\hline & Bigelowia nuttallii & Forb & 4 \\
\hline & Eriophyllum lanatum & Forb & 4 \\
\hline & Hieracium aurantiacum & Forb & 4 \\
\hline & Solidago bicolor & Forb & 4 \\
\hline Brassicaceae & Aurinia saxatilis & Forb & 3 \\
\hline Cactaceae & Opuntia humifusa & Hardy Succulent & 5 \\
\hline \multirow{2}{*}{ Campanulaceae } & Campanula poscharskyana & Forb & 3 \\
\hline & Campanula rotundifolia & Forb & 3 \\
\hline \multirow{6}{*}{ Caryophyllaceae } & Cerastium tomentosum & Forb & 4 \\
\hline & Dianthus arenarius & Forb & 3 \\
\hline & Dianthus carthusianorum & Forb & 3 \\
\hline & Dianthus deltoides & Forb & 3 \\
\hline & Petrohagia saxifraga & Forb & 6 \\
\hline & Sagina procumbens & Forb & 4 \\
\hline \multirow{3}{*}{ Caryophyllaceae } & Saponaria ocymoides & Forb & 2 \\
\hline & Silene acaulis & Forb & 2 \\
\hline & Silene caroliniana & Forb & 6 \\
\hline \multirow{5}{*}{ Crassulaceae } & Jobibarba & Hardy Succulent & 4 \\
\hline & Orostachys aggregeatum & Hardy Succulent & 6 \\
\hline & Orostachys boehmeri & Hardy Succulent & 4 \\
\hline & Orostachys malacophyllus & Hardy Succulent & 4 \\
\hline & Phedimus takesimensis & Hardy Succulent & 4 \\
\hline
\end{tabular}


Family

Crassulaceae

\begin{tabular}{|c|c|c|}
\hline Scientific Name & Vegetation Type & $\begin{array}{c}\text { Hardiness } \\
\text { Zone } \\
\text { (Upper Limit) }\end{array}$ \\
\hline Sedum acre & Hardy Succulent & 4 \\
\hline Sedum aizoon & Hardy Succulent & 4 \\
\hline Sedum album & Hardy Succulent & 4 \\
\hline Sedum apoleipon & hardy succulent & 7 \\
\hline Sedum cauticola & hardy succulent & 4 \\
\hline Sedum cyaneum & Hardy Succulent & 5 \\
\hline Sedum dasyphyllum & Hardy Succulent & 8 \\
\hline Sedum diffusum & Hardy Succulent & 8 \\
\hline Sedum ellacombianum & Hardy Succulent & 5 \\
\hline Sedum ewersii & Hardy Succulent & 5 \\
\hline Sedum floriferum & Hardy Succulent & 3 \\
\hline Sedum forsterianum & Hardy Succulent & 4 \\
\hline Sedum glaucophyllum & Hardy Succulent & 5 \\
\hline Sedum gracile & Hardy Succulent & 5 \\
\hline Sedum grisbachii & Hardy Succulent & 5 \\
\hline Sedum hispanicum & Hardy Succulent & 6 \\
\hline Sedum hybridum & Hardy Succulent & 4 \\
\hline Sedum japonicum & Hardy Succulent & 5 \\
\hline Sedum kamtschaticum & Hardy Succulent & 4 \\
\hline Sedum lineare & Tender Succulent & 7 \\
\hline Sedum lydium & Hardy Succulent & 5 \\
\hline Sedum makinoi & Hardy Succulent & 7 \\
\hline Sedum mexicanum & Hardy Succulent & 7 \\
\hline Sedum middendorffianum & Hardy Succulent & 5 \\
\hline Sedum montanum & Hardy Succulent & 8 \\
\hline Sedum moranense & Hardy Succulent & 5 \\
\hline Sedum ochroleucum & Hardy Succulent & 5 \\
\hline Sedum oreganum & Hardy Succulent & 5 \\
\hline Sedum pachyclados & Hardy Succulent & 8 \\
\hline Sedum pluricaule & Hardy Succulent & 6 \\
\hline Sedum populifolium & Hardy Succulent & 3 \\
\hline Sedum pulchellum & Hardy Succulent & 5 \\
\hline Sedum reflexum & Hardy Succulent & 4 \\
\hline Sedum rupestre & Hardy Succulent & 4 \\
\hline Sedum sarmentosum & Hardy Succulent & 3 \\
\hline Sedum sediforme & Hardy Succulent & 4 \\
\hline Sedum selskianum & Hardy Succulent & 4 \\
\hline Sedum sexangulare & Hardy Succulent & 4 \\
\hline Sedum sichotense & Hardy Succulent & 4 \\
\hline Sedum sieboldii & Hardy Succulent & 5 \\
\hline Sedum spathulifolium & Hardy Succulent & 4 \\
\hline Sedum spurium & Hardy Succulent & 5 \\
\hline Sedum stefco & Hardy Succulent & 5 \\
\hline Sedum stenopetalum & Hardy Succulent & 7 \\
\hline
\end{tabular}




\begin{tabular}{|c|c|c|c|}
\hline \multirow{8}{*}{ Crassulaceae } & Scientific Name & Vegetation Type & $\begin{array}{c}\text { Hardiness } \\
\text { Zone } \\
\text { (Upper Limit) }\end{array}$ \\
\hline & Sedum takesimense & Hardy Succulent & 6 \\
\hline & Sedum telephioides & Hardy Succulent & 5 \\
\hline & Sedum telephium & Hardy Succulent & 5 \\
\hline & Sedum ternatum & Hardy Succulent & 5 \\
\hline & Sedum tetractinum & Hardy Succulent & 6 \\
\hline & Sedum urvillei & Hardy Succulent & 6 \\
\hline & Sempervivum sp. & Hardy Succulent & 4 \\
\hline \multirow{7}{*}{ Cyperaceae } & Carex flacca & Grass & 5 \\
\hline & Carex flaccosperma & Grass & 5 \\
\hline & Carex humilis & Grass & 4 \\
\hline & Carex nigra & Grass & 4 \\
\hline & Carex stricta & Grass & 5 \\
\hline & Carex pansa & Grass & 3 \\
\hline & Carex tumulicola & Grass & 2 \\
\hline Dipsacaceae & Scabiosa columbaria & Forb & 3 \\
\hline \multirow{3}{*}{ Ericaceae } & Empetrum nigrum & Shrub & 4 \\
\hline & Gaultheria procumbens & Shrub & 3 \\
\hline & Vaccinium vitis-idaea & Shrub & 4 \\
\hline Iridaceae & Sisyrinchium douglasii & Forb & 5 \\
\hline \multirow{5}{*}{ Lamiaceae } & Lavandula angustifolia & Forb & 4 \\
\hline & Origanum vulgare & Forb & 5 \\
\hline & Thymus praecox & Forb & 4 \\
\hline & Thymus pseudolanuginosus & Forb & 4 \\
\hline & Thymus serphyllum & Forb & 5 \\
\hline Liliaceae & Camassia quamash & Forb & 6 \\
\hline Papaveraceae & Escholzia maritima & Forb & 3 \\
\hline Plantaginaceae & Plantago maritima & Forb & 3 \\
\hline Plumbaginaceae & Armeria maritima & Forb & 4 \\
\hline \multirow{15}{*}{ Poaceae } & Argostis pallens & Grass & 7 \\
\hline & Bouteloua gracilis & Grass & 4 \\
\hline & Calamagrostis stricta & Grass & 2 \\
\hline & Danthonia spicata & Grass & 4 \\
\hline & Deschampsia flexuosa & Grass & 3 \\
\hline & Festuca glauca & Grass & 4 \\
\hline & Festuca idahoense & Grass & 3 \\
\hline & Festuca ovina & Grass & 4 \\
\hline & Festuca rubra & Grass & 4 \\
\hline & Festuca scoparia & Grass & 4 \\
\hline & Koeleria gluaca & Grass & 4 \\
\hline & Koeleria macrantha & Grass & 2 \\
\hline & Koeleria micrantha & Grass & 4 \\
\hline & Phlox subulata & Forb & 4 \\
\hline & Poa compressa & Grass & 3 \\
\hline
\end{tabular}




\begin{tabular}{|c|l|c|c|}
\hline \multirow{5}{*}{ Family } & Sesleria autumnalis & Grass & 6 \\
\hline Polemoniaceae & \multicolumn{1}{|c|}{ Scientific Name } & Vegetation Type & $\begin{array}{c}\text { Hone } \\
\text { Zoper Limit) }\end{array}$ \\
\hline \multirow{5}{*}{ Portulacaceae } & Sporobolus heterolepis & Grass & 6 \\
\cline { 2 - 4 } & Talinum calycinum & Forb & 8 \\
\cline { 2 - 4 } & Talinum paniculatum & Forb & 6 \\
\cline { 2 - 4 } & Talinum parviflorum & Forb & 6 \\
\cline { 2 - 4 } & Talinum rugospermum & Hardy Succulent & 6 \\
\cline { 2 - 4 } & Talinum teretifolium & Forb & 4 \\
\hline \multirow{5}{*}{ Rosaceae } & Fragaria chiloensis & Forb & 7 \\
\cline { 2 - 4 } & Fragaria virginiana & Forb & 5 \\
\hline \multirow{5}{*}{ Scrophulariaceae } & Penstemon barbatus & Forb & 6 \\
\cline { 2 - 4 } & Penstemon pinifolius & Forb & 4 \\
\cline { 2 - 4 } & Veronica liwanensis & Forb & 4 \\
\cline { 2 - 4 } & Veronica prostrata & Forb & 3 \\
\cline { 2 - 4 } & Veronica whitleyi & . & 5 \\
\hline
\end{tabular}

(Lundholm et al., 2010; Emory Knoll Farms, 2011; Etera, 2011; Mothersplants, 2011; Nat's Nursery, 2011) 